\title{
Ecological distribution of Vibrios and their significance in coastal ecosystem
}

\author{
Yan-Ling Wang and Ji-Dong Gu* \\ Laboratory of Environmental Microbiology/Toxicology, School of Biological Sciences, The University of Hong Kong, Pokfulam Road, \\ Hong Kong SAR, P.R. China
}

\begin{abstract}
Coastal ecosystem is important because it bridges ocean and land. The brackish water receiving nutrients originated from land may nourish heterotrophic bacteria including Vibrio species, some of which may pose potential hazards to the public, marine lives and migratory birds in the coastal environment. A rich diversity of Vibrios is evident in the coastal and open oceans, but information on their ecophysiological adaptation and survival is still very limited. Their important roles in the geobiochemical cycles of nutrients have not been exolored adequately. In addition, it also been recently discovered that these Vibrios harbor a very rich of plasmids of various sizes with little knowledge on their function to the hosts. This information deserves attention in Vibrio ecology and their role in the various ecosystems for a better understanding of their survival and physiological function.

Keywords:Vibrio species; pathogenic; pollution; plasmids; ecological role
\end{abstract}

* Correspondence to: Ji-Dong Gu, Laboratory of Environmental Microbiology/Toxicology, School of Biological Sciences, The University of Hong Kong, Pokfulam Road, Hong Kong SAR, P.R. China; E-mail: jdgu@hku.hk

Received: May 17, 2018; Accepted: September 17, 2018; Published Online: October 11, 2018

Citation: Yan-Ling Wang and Ji-Dong Gu, 2018. Ecological distribution of Vibrios and their significance in coastal ecosystem. http://doi.org/10.26789/AEB.2018.02.002.

Copyright:Ecological distribution of Vibrios and their significance in coastal ecosystem.@ 2018 Yan-Ling Wang and Ji-Dong Gu. This is an Open Access article distributed under the terms of the Creative Commons Attribution-Noncommercial 4.0 International License, permitting all non-commercial use, distribution, and reproduction in any medium, provided the original work is properly cited and acknowledged.

\section{Introduction}

Vibrio is an old bacterial genus that was first described in the 1800s. The genus name, Vibrio, was coined by Pacini in 1854 during his study on cholera disease. Numerous researchers after Pacini subsequently conducted extensive investigations on this group of heterotrophic bacteria are indigenous to aquatic environments, such as ocean, river, inter-tidal water and ponds. Vibrio species are Gram negative, straight or curved rods or spirals, and motile by means of flagella (Farmer III and Hickman-Brenner, 1992). Similar to Pseudomonas, this is a "big" genus consisting of large number of heterogenous species and isolates, at least 60 different species and many more bacterial isolates are described in this group (www.ncbi.nlm.nih.gov/Taxonomy/Browser/wwwtax.cgi). As the development of molecular techniques, more new species of Vibrio are unraveled and published (Thompson et al., 2005).

Over the history, much of the research on Vibrio came initially from medicine and clinical microbiology, and was primarily related to cholera disease, the diarrhea symptom caused by Vibrio cholerae, one of the most infamous species in this genus. Other notorious species that are of public health importance include $V$. minicus, V. parahaemolyticus, $V$. hollisae, and V. cincinnatiensis, etc. Selective species, such as $V$. anguillarum and V. salmonicida, do not occur in human clinical specimens, but they are fish pathogens posing a serious threat to aquaculture (Farmer III and Hickman-Brenner, 1992). Vibrio shiloi, capable of biosynthesizing and secreting an extracellular peptide (toxin P), inhibits the photosynthesis of coral symbiotic algae (zooxanthellae) and is responsible for the coral bleaching in marine ecosystem (Banin et al., 2000). Although some species of Vibrio are of human and animal health concerns, others contribute to the new discoveries and technological development in basic microbiology and biochemistry. Bioluminescence was first found in V. fischei, a bacterium named after Bernhard Fisher (Farmer III and Hickman-Brenner, 1992). Lux, a marker gene widely applied in environmental microbiology and microbial ecology to label and track a selective microorganism of interest, is cloned from this species of Vibrio. Based on the study of bioluminescence in $V$. fischei and $V$. harveyi, Nealson was the first to propose quorum-sensing mechanism that regulates the bioluminescence and bacterial biofilm formation on surfaces (Nealson and Hasting) and Hasting, (Madigan et al., 2003a; Madigan et al., 2003b; Madigan et al., 2003c; Madigan et al., 2003d; Madigan et al., 2003e; Madigan et al., 2003f).

And such gene-regulation mechanism has been confirmed to be ubiquitous among many other terrestrial bacteria as well (Madigan et al., 2003a; Madigan et al., 2003b; Madigan et al., 2003c; Madigan et al., 2003d; Madigan et al., 2003e; Madigan et al., 2003f). Found worldwide, Vibrio species 
reside primarily in marine and brackish waters as well as contaminated water including drinking water sources.

Nature reserve including the local one are breeding sites and feeding grounds for a high diversity of coastal species, such as shellfish, migratory birds and grounddwelling benthic animals and infauna (Tsim and Lock, 2002). Mai Po Nature Reserve holds the largest mangrove stands in Hong Kong and is under pollution from discharge of Shenzhen River and Sham Pui River carrying nutrients-rich water into the reserve. Brackish (slightly salt) water bathing the mangroves contains a diverse community of phytoplankton, zooplankton and water-borne microorganisms (Lin, 1999; Wang et al., 2004; Wang et al., 2006; Zhang and Gu, 2009; Zhang et al., 2006; Zhang et al., 2007; Zhang et al., 2012). Though a number of studies on the ecology of Mai Po Nature Reserve have been conducted in the past two to three decades, little research has ever been carried out to investigate bacterial community, let alone Vibrio species. Therefore, the objectives of this study were to isolate and characterize Vibrio species from Mai Po Nature Reserve and to establish relationship between unique characteristics and the molecular basis. This literature review will cover the following topics: 1) introduction of Mai Po Nature Reserve; 2) Vibrio species and their ecology; 3) antibiotic resistance and plasmid profile in Vibrio species.

\section{Vibrio Species and Their Ecology}

\subsection{Vibrio Species}

Cholera is a disease immediately associated with public health and environmental quality; a new branch of public health microbiology was established through the initial investigation by John Snow in London. The causative agent of cholera is Vibrio cholerae, one of the most well known species in Vibrio. As a genus, these facultative bacteria, belonging to Vibrio species, are small comma-shaped rods that live in a wide range of aquatic environment or inside human and animal intestines (Lowrie and Borneman, 1999). Vibrio species are members of the family Vibrio nacae, which also contains other three genera including Aeromonas, Plesiomonas and Photobacterium with similar characteristics. The bacteria of these four genera are all Gram negative, calatase and oxidase positive, but they can be differentiated by DNA-DNA hybridization and also other distinctive characteristics. For example, DNA-DNA hybridization shows that Plesiomonas shigelloides and Aeromonas do not have any close relativeness to Vibrio or Photobacterium. Aeromonas genus has a $\mathrm{G}+\mathrm{C}$ content of $57-63 \%$, which is high in the Vibrionacae family. Plesiomonas species fail to grow on the highly selective Thiosulphate-Citrate-Bile saltsSucrose (TCBS) agar plates, while this selective medium is specially designed for the selective isolation of Vibrio species from environmental samples. In addition, vibriostatic agent, O/129 (2,4-diamino-6,7-diisopropylpteridinephosphate) can inhibit the growth of Vibrio species, but has no effect on
Aeromonas. The sheathed polar flagella in Vibrio species are important to their movement and bacterial pathogenesis, but all the other three genera do not have such intricate structure in their cells (Collee et al., 1989; Farmer III, 1992.).

Some biochemical characteristics of Vibrio species can also be used to differentiate them from other close families in the $\gamma$-group microorganisms. Vibrio species can be separated from Enterobacteriaceae by a simple oxidase test. Due to the absence of oxidase in Enterobacteriaceae, they do not turn purple on the testing filter paper, showing a negative signal. The facultative Vibrio species can grow under both aerobic and anaerobic conditions. In contrast, Pseudomonas species only grow in the presence of oxygen as their electron acceptor. Salt requirement is crucial for some species of Vibrio, while available $\mathrm{Na}^{+}$is not required for the growth of Enterobacteriaceae and Pseudomonadaceae (Farmer III, 1992.; Lowrie and Borneman, 1999).

Due to their wide distribution in seawater, Vibrio species have been found worldwide, mainly in marine and brackish water such as coastal waters and estuaries as well as drinking water. Most often, they prefer aquatic environments with rich nutrients and warm temperature. A polluted, relatively physical undisturbed habitat with $\mathrm{pH}$ of 8.0 to 9.0 can be optimal for Vibrio survival and proliferation (Lowrie and Borneman, 1999). Most Vibrio species grow well in the salinities ranged from 5 to $30 \%$. There are four major factors that govern their distribution: the selective animals or plant hosts, temperature, salinity, and depth below the surface for the species that are found in the ocean (Simidu et al., 1985). The incidence and density of pathogenic Vibrio species decrease significantly as water temperatures fall below $20^{\circ} \mathrm{C}(221)$. The pathogenic $V$. cholerae serogroup $\mathrm{O} 1$ is obviously host-adapted and is limited to humans as its host where it causes the disease cholera (Farmer III, 1992.). Other environmental isolates of Vibrio species are also found in water column, surface sediment or in association with mollusks and crustaceans (Said and Drasar, 1996). Those species common to open ocean or low nutrient water tend to be smaller and coccoid in shape. It has been reported that multiple-nutrient starvation resulted in a decrease of cell volume by as much as $85 \%$ in V. cholerae (Baker et al., 1983). The reduced cell size will increase the surface-to-volume ration thereby aiding cells in sequestering more nutrients under the oligotrophic environment. And the smaller cell size will also enhance the bacterial survival by protecting against predation (Byrd, 2000). In fact, the morphological change in cell size is a basic strategy for Vibrio species to survive under the starvation condition and stress of natural ecosystem. By living symbiotically with phytoplankton and zooplankton, Vibrio species gain a better chance to survive under the low temperature condition and to avoid predation by protozoa. Sometimes, sediment can also serve as reservoir for them by providing organic nutrients and shelter from coldness in winter season (Tamplin et al., 1990). 
Much work has been conducted to isolate Vibrio species from natural environment, marine animals, plants and the intestinal tract of marine vertebrates. Some species in this group are pathogenic to commercially important fish, oyster and crabs. Some are toxic to higher animals like birds and humans. In the following section, several representatives of Vibrio species will be discussed.

\subsection{Non-pathogenic Vibrio Species}

Except for those Vibrio species that occur in human clinical specimens, there are about 20 marine species without obvious evidence of any disease association. Theoretically, these marine vibrios could occur in animal feces and pose potential health threat following ingestion of environmental water or not-well cooked seafood. Although some of the species are not proven human-pathogens, they are bacterial pathogens to many animals such as fish, oyster, crab, shrimp and even coral (Farmer III and Hickman-Brenner, 1992).

Vibrio anguillarum is a marine vibrio species that causes disease in marine fish and other marine animals. It is a major hazard to fish farms resulting in great economic loss. The infection by $V$. anguillarum to oysters and shellfish inhibits larval swimming to loss of digestive function in adult shellfish. Poor water quality, over-crowding in aquaculture facilities, heavy nutrient loading and high temperature (above $15^{\circ} \mathrm{C}$ ) all contribute to the increasing occurrence of $V$. anguillarum and subsequent outbreak of vibrio infection in aquculture (Farmer III and Hickman-Brenner, 1992; Lowrie and Borneman, 1999).

Vibrio alginolyticus is pathogenic to a wide range of marine life including fish, mollusks, crustaceans and cnidarians. It can be found in open ocean, estuaries, sediments, marine life, coral and freshwater, indicating its strong adaptive capability to survive in various aquatic environments. Through exposure to marine water, wounds may be the point of entry for infection by $V$. alginolyticus. As a halophilic marine bacterium, it only grows in the presence of $\mathrm{NaCl}$ at concentration and can be as high as $10 \%$ (Tison, 1999).

Vibrio fischeri is a halophilic bioluminescent Vibrio species. Under the optimal growth conditions, it produces detectable fluorescence. Colonized in specialized organs in fish or squid, this bacterium is of vital importance to the attraction of prey and camouflage in its host animals living in dark deep-ocean. The sites of common occurrence of $V$. fischeri are open ocean, estuaries, fish and crustaceans. In some cases, it may cause gut and organ distention and swelling in the fish. Temperature of $37^{\circ} \mathrm{C}$ can slower down the bacterial growth while $30^{\circ} \mathrm{C}$ is optimal (Farmer III and Hickman-Brenner, 1992; Lowrie and Borneman, 1999).

Another halophilic bioluminescent vibrio is Vibrio harveyi. Some strains of this bacterium are bioluminescent, other are not. Density-dependent expression of luminescence in $V$. harveyi is regulated by the concentration of extracellular signal molecules (autoinducers) in the culture medium and a multiple signaling system of regulating the bioluminescence has been proposed (Bassler et al., 1994). Its virulence to an expanding list of marine animals has been associated with the extracellular products and a toxic cysteine protease. The cysteine protease secreted by $V$. harveyi causes co-agglutination in prawn plasma which leads to uncoverable hemolymph. This event significantly contributes to the pathogenicity of this bacterium in the prawns under farming conditions (Lee et al., 1999).

Vibrio shiloi is believed to be the causative agent of coral bleaching in the Mediterranean Sea area. The $\beta$-galactose receptor aids $V$. shiloi to recognize and adheres to the coral surface followed by bacterial penetration to coral tissue. Then, the bacteria multiply in the coral tissue and even enter non-culturable state. In addition, the bacteria can produce heat-stable extracellular toxin to inhibit the photosynthesis of zooxanthellae and heat-sensitive toxin to bleach and lyse algal cells (Banin et al., 2000). It is quite interesting that coral bleaching was affected greatly by temperature. Both laboratory aquarium experiment and natural bleaching shows that a rapid bleaching occurs at about $30^{\circ} \mathrm{C}$ and no bleaching was noticeable at $16^{\circ} \mathrm{C}$. It is proposed that temperature-regulated factors may play a role in bacterial virulence in the bleaching process to coral (Kushmaro et al., 1998).

Due to the length constrains, not every Vibrio species can be introduced or discussed here. What has been mentioned above are only representative species. It must be pointed that though some Vibrio species are a potential danger to marine life in aquaria and natural aquatic environment, they should not be treated with shear fear but thorough understanding to minimize the potential threat. More work remains to be done to elucidate their role and the presence in the natural environment.

\subsection{Pathogenic Vibrio Species}

Ranking high as major human public health threats, some of Vibrio species cause a number of primary enteric infections. Human disease may result from ingestion of water contained with pathogenic Vibrio species, consumption of infected seafood, or exposure of wounds to water where active pathogenic Vibrio species are present (Lowrie and Borneman, 1999). Among all the Vibrio species, there are at least twelve species of clinical significance. They are listed below in the order of medical importance: $V$. choleare O1, V. cholerae O139, V. cholerae non-O1, V. parahaemolyticus, V. vulnificus, V. hollisae, V. alginolyticus, V. minicus, V. damsela, V. fluvialis, V. metschnikovii, V. furnissii, $V$. cincinnatiensis and $V$. carchariae. The diseases associated with these pathogenic Vibrio species comprise cholera, gastroenteritis, bacteremia, wound infections and 
meningitis. And the major clinical sources from which these species are isolated are feces, blood, wound and ear (Tison, 1999). The polar or lateral flagella not only facilitate the bacterial motility in natural environment but also aid in attachment of Vibrio species to substrates. The pathogenic Vibrio species also produce various toxins such as hemolysins, exotoxins and enterotoxins as part of bacterial pathogenesis mechanisms (Lowrie and Borneman, 1999).

The following section will cover the introduction of three most life-threatening Vibrio species: V. parahaemolyticus, V. vulnificus and V. cholerae. Their characteristics, pathogenesis and ecology are to be introduced below.

\subsubsection{Vibrio parahaemolyticus}

Vibrio parahaemolyticus was first isolated and identified as a causative agent of human disease after an outbreak of acute gastroenteritis in Japan in 1950. A food poisoning due to the consumption of contaminated seafood claimed 20 deaths and 272 cases of acute gastroenteritis in Osaka, Japan. Subsequent extensive investigations revealed an organism to be the etiological agent, which was later named and reclassified as V. parahaemolyticus in 1955 (Farmer III and Hickman-Brenner, 1992). Consumption of raw seafood such as oyster and shellfish is a main transmission route for disease development worldwide. Wound, eye and ear infections may also occasionally result from exposure to the marine water where the bacterium is present at relative high population density. The common characteristics of $V$. parahaemolyticus gastroenteritis include nausea, vomiting, abdominal cramps, low-grade fever and chills. The diarrhea is watery and occasionally bloody (Tison, 1999). Ninety-six percent of gastroenteritis-causing $V$. parahaemolyticus are positive for Kanagawa Test meaning that the strain can produce a hemolysin for human red cells. But, only $1 \%$ of environmental isolates are positive for Kanagawa test (Farmer III and Hickman-Brenner, 1992). Rehydration is sufficient and effective for the treatment but in case of severe diarrhea, hospital admission is necessary.

The $V$. parahaemolytics strains positive for Kanagawa Test produce an enterotoxin called thermostable direct hemolysin $(\mathrm{TDH})$, a major virulence factor responsible for bacterial pathogenesis. This hemolysin cannot be inactivated by heating at $100^{\circ} \mathrm{C}$ for 10 minutes and the hemolytic activity is not enhanced by the addition of lecithin indicating a direct action on erythrocytes (Nishibuchi and Kaper, 1995). Acting as a pore-forming toxin, TDH plays an important role in altering the ion flux in intestinal cells thereby leading to a secretory response and diarrhea (Honda et al., 1992; Huntley et al., 1993). Another virulence factor, the TDH-related hemolysin $(T R H)$ is generally associated with the Kanagawa Test negative strains or with urease positive strains of $V$. parahaemolyticus. Its trh gene may be part of a pathogenicity island. Both tdh and trh genes have been widely used as DNA probes and PCR amplification targets in the determination of pathogenic V. parahaemolytic of various sources (DePaola et al., 2003).

Morphological observation reveals that V. parahaemolyticus is a short Gram negative rod and actively motile in liquid cultures. It is halophilic and fails to grow in peptone water without any $\mathrm{NaCl}$ supplement (Collee et al., 1989). It can grow well on TCBS agar plates as greenish-blue colonies, two to three millimeter in diameter. Susceptible to vibriostatic agent $\mathrm{O} / 129, V$. parahaemolyticus, however, displays a relatively resistance compared to $V$. cholerae (Collee et al., 1989)

As a common marine bacterium, V. parahaemolyticus is frequently isolated from sediments, seawater and crustaceans. And its main habitat is probably marine animals with human infection being a second development(Madigan et al., 2003a; Madigan et al., 2003b; Madigan et al., 2003c; Madigan et al., 2003d; Madigan et al., 2003e; Madigan et al., 2003f). It has been isolated from marine and estuarine habitats almost worldwide and despite its halophilic nature. Winter survival of this bacterium has been found to be associated to other marine organisms, copepods in particular. Growth rates are directly related to temperature and the bacterium is rarely found when water temperatures are below $15^{\circ} \mathrm{C}$ (Joseph et al., 1982). The bacteria may survival at freezing conditions in shellfish and seafood though at a much lower frequency (Oregon Department of Human Services, 2003). In summer, however, more cases of $V$. parahaemolyticys infection tend to be reported. High temperature at 37 to $42^{\circ} \mathrm{C}$ can activate specific heat-shocking proteins and adaptive acid tolerance proteins in the pathogen so that it can stand very acidic environment. Interestingly, the bile-acid-containing environment found in human host favors the growth of virulent strains of V. parahaemolyticus and even enhances the expression of virulent factors (Huq et al., 2000).

\subsubsection{Vibrio vulnificus}

Next to the infamous Vibrio cholerae, Vibrio vulnificus causes the most severe disease. It was originally described by Hoillis as a salt-required organism, distinct from other species of Vibrio by its ability to ferment lactose (Hollis et al., 1976). Once named as Beneckea vulnifica, it is now universally accepted as $V$. vulnificus (Farmer III and Hickman-Brenner, 1992). Raw oyster consumption by humans is the predominant transmission vehicle of this bacterium. This is quite different from other Vibrio species whose transmission vectors cover mollusks and crustaceans as well (Tison, 1999). The septicemia and wound infection caused by $V$. vulnificus progress so rapidly that some are fatal. This bacterium is especially dangerous to people with pre-existing hepatic disease. The increased iron availability due to the liver disease put these individuals at a high risk of being attacked by V. vulnificus (Tison, 1999). Gastroenteritis, septicemia, meningitis, pneumonia and keratitis are various diseases caused by this life-threatening pathogen (Farmer III 
and Hickman-Brenner, 1992). Additionally, V. vulnificus is responsible for skin lesions and necrosis in eels and other susceptible fish all over the world (Lowrie and Borneman, 1999).

Due to its fatality caused to both humans and marine life, $V$. vulnificus has become a research focus for many years. There are considerable variations among the environmental isolates of this bacterium. Sensitive virulence assay with animal model has demonstrated that there are both virulent and avirulent strains (Stelma et al., 1992). The experiment attempting to correlate a particular factor to virulence has proven largely unsuccessful, suggesting that multiple factors contribute to the bacterial pathogenesis (Strom and Paranjpye, 2000). The first virulence factor proven to correlate positively to virulent strain is polysaccharide capsule (PC) surrounding the bacterial cells. Mutations in any gene that adversely affect PC biosynthesis result in a measurable decrease in virulence by $V$. vulnificus (Zuppardo and Siebeling, 1998). Pili, also called fimbriae, mediate the initial attachment and colonization of $V$. vulnificus to its host. The Type IV pili in this bacterium have been isolated and proven to display a comparative similarity to those in V. cholerae and other pathogens (Strom and Paranjpye, 2000). Secretion of toxins and enzymes such as chitinases are other mechanisms that facilitate $V$. vulnificus to colonize and adhere to the zooplankton and molluscan shellfish (Strom and Paranjpye, 2000). Cytolysin, one of the most studied hemolysins, is a heat-resistant lytic enzyme that lyses mammalian erythrocytes. This toxin can activates guanylate cyclase to increase the concentration of intracellular cyclic GMP levels, resulting in vasodilation (Kook, 1999). V. vulnificus also produces an extracellular protease that has elastolytic and collagenolytic activity. It is designated as metalloprotease. In its pure form, this protein induces hemmorhagic damage and enhances vascular permeability, suggesting its potential virulence in skin lesions (Strom and Paranjpye, 2000). A successful recruitment of enough iron from iron-transporting proteins is crucial for the virulence of $V$. vulnificus. Therefore, the production of hydroxymate and phenolate siderophores ensures the sequestration of iron from host transferrin and hemoglobin. Failure to produce significant siderophores has been associated with reduced virulence in this bacterial pathogen (Simpson and Oliver, 1983).

The sensitive Random Amplification of Polymorphic DNA (RAPD)-PCR technique was recently applied to compare clinical and environmental isolates of $V$. vulnificus. A unique 178 to 200 -base pair segment is presented in all clinical isolates but in only a small proportion of environmental isolates. And this unique segment may be used as DNA probe for pathogenic V. vulnificus (Warner and Oliver, 1999). Typing of bacteriophage specific to clinical $V$. vulnificus is another method to differentiate environmental isolates from clinical ones. Some virulence factors may originate from certain bacteriophage (DePaola et al., 1998).
V. vulnificus is phenotypically similar to V. parahaemolyticus. Most strains of $V$. vulnificus form green, non-sucrose fermentative colonies on TCBS agar plates. The ability of fermenting lactose is a distinct feature to differentiate $V$. vulnificus from other Vibrio species. The absence of $\mathrm{NaCl}$ addition or high concentration of salt $(\geqq 8 \%)$ can curb the bacterial growth in the nutrient broth completely. Very sensitive to vibriostatic agent, $V$. vulnificus does not grow in the presence of $10 \mu \mathrm{g} / \mathrm{ml}$ of O/129 (Farmer III and Hickman-Brenner, 1992).

V. vulnificus is a naturally occurring, free-living inhabitant of estuarine and marine environment. And its presence in estuarine environment may not be related to pollution or other forms of contamination (Høi et al., 1998). Preferring to warm climates, it has been isolated mostly from waters where temperatures range from 10 to $30^{\circ} \mathrm{C}$. When the temperature exceeds $18^{\circ} \mathrm{C}$, it can multiply quite well (Kaspar and Tamplin. 1993) However, if temperature is less than $10^{\circ} \mathrm{C}$, the total viable count drops greatly, almost to undetectable level (Strom and Paranjpye, 2000). Temperature is proposed to be an important factor inducing the bacterial entry to VBNC state. V. vulnificus, incubated at $5^{\circ} \mathrm{C}$, enters into $\mathrm{VBNC}$ state no matter it was in nutrientdeplete artificial seawater or nutrient broth (Oliver, 2000). Physiological age of bacterial cells seems to be another factor that affects the time required for entry to VBNC state. Cells in stationary phase took twice the time to become nonculturable at $5^{\circ} \mathrm{C}$ than did logarithmic-phase cells (Oliver et al., 1991). Transferred from normal temperature $\left(22^{\circ} \mathrm{C}\right)$ to low temperature $\left(4^{\circ} \mathrm{C}\right)$, there was an observable decrease in biosynthesis of macromolecules in $\mathrm{V}$. vulnificus, suggesting signal transduction occurred in response to down-shift of temperature. Along with an immediate decline in protein synthesis, some "cold shock" proteins were also induced to ensure survival in cold environment (Oliver, 2000). Morphological changes in cell size along with alteration in membrane fatty acid profile can also be noticed after bacterial entry to VBNC state (Strom and Paranjpye, 2000). However, the potential virulence of $V$. vulnificus in VBNC state can never be overlooked. Even a small dosage of VBNC cells of this bacterium is sufficient to kill mice (Oliver, 1993).

Generally speaking, low to moderate salinity favors the growth of $V$. vulnificus, whose normal salinity range falls between 1.5 to $2.5 \%$ (Strom and Paranjpye, 2000). With its chitinase activity, V. vulnificus may associate with zooplankton or other filter-feeding mollusks such as oysters, clams and mussels. The bacterium can be accumulated and reside in animal gut or other tissues. Its concentration in fish intestines is also well-documented and fish may serve as a reservoir for the transport of the bacterium (Motes et al., 1998). The association of $V$. vulnificus with zooplankton and phytoplankton or its attachment to soft submerged sediments is an effective tactics to survive in stressful conditions like coldness and starvation (Strom and Paranjpye, 2000). 


\subsubsection{Vibrio cholerae}

Vibrio cholerae is by far the best understood species in the genus of Vibrio. As the causative agent of cholera, it has claimed millions of deaths and become one of the most feared bacterial pathogens in history. This organism was first described by Pancini in 1854, the same year John Snow investigated the link between drinking water quality and cholera in London. Then Robert Koch confirmed its bacterial etiology in 1883 when he successfully isolated the cholera bacillus from pond water during a cholera outbreak in Egypt (Said and Drasar, 1996). Classified by serological testing for $\mathrm{O}$ antigen determinants, $V$. cholerae can be subdivided into three major groups, $V$. cholerae $\mathrm{O} 1$, $V$. cholerae non-O1 and V. cholerae O139 Bengal. And V. cholerae $\mathrm{O} 1$ can be further categorized into three subtypes: Inaba, Ogawa and Hikojima, based on the agglutination with specific antisera. The bio-grouping of $V$. cholerae O1 into Classical and El Tor is also widely used, when mentioning the etiologic agent of epidemic cholera (Said and Drasar, 1996). Cholera was often documented in early writings as Asiatic cholera due to its epidemic range in India. However, since 1800, there have been seven severe pandemics of cholera recorded over the medical history. The first pandemic began in 1816-1817 and six other pandemics were reported with a beginning in $1829,1852,1863,1881$, 1889 , and 1961 respectively. Although the seventh pandemic in 1961 was caused by the El Tor, the Classical biogroup, responsible for the previous six pandemics, has displaced the El Tor in some parts of the Indian subcontinent (Farmer III and Hickman-Brenner, 1992). The general belief that cholera is only limited to $V$. cholerae $\mathrm{O} 1$ was challenged in October, 1992. An epidemic of cholera outbreak in Madras, India was confirmed to be caused by a newly-emerged $V$. cholerae serogroup, designated as O 139 Bengal. This group of $V$. cholerae appeared to spread very rapidly from India to United Kingdom to United States, accountable for a wide-sweeping of cholera outbreak in 1994 and 1996 (Tison, 1999).

In the area of cholera epidemic, individuals who ingested $V$. cholerae may have either mild diarrhea or very acute symptoms. In extreme cases, patients will develop an acute diarrhea with constant purging that has been called "cholera gravis." Vomiting and no desire to eat are also commonly accompanied symptoms. If left untreated, the patient will encounter more severe dehydration, electrolyte imbalance, painful muscle cramps, watery eyes, loss of skin elasticity and anuria. The death from dehydration is usually imminent after onset of above-mentioned symptoms (Farmer III and Hickman-Brenner, 1992). Most often, the immediate medical treatment and management can prevent the fatality of patient with cholera. The widely practiced management includes: 1) rapid replacement of water and salt(s);2) maintenance of normal hydration; 3) reduction of both magnitude and duration of diarrhea; and 4) prompt introduction of normal diet to minimize the nutrient loss (Cook, 1996).
Other serogroups besides O1/ O139 have been collectively referred to $V$. cholera non-O1. Though they do not produce cholera toxin nor cause cholera epidemic, they are etiologic agents of self-limiting gastroenteritis and some may cause wound-infections and bacteremia (Tison, 1999). In this large and diverse species, there are still other harmless aquatic strains. Lack of toxin-producing genetic elements in their genome, non-pathogenic $V$. cholerae non-O1 live freely in natural environment. But due to similarity to the pathogenic counterparts, they have a potential to "up-take" pathogenicity islands and convert to toxic strains (Karaolis et al., 1998).

The efforts to search for an effective cholera vaccine have mainly focused on the bacterial pathogenesis or virulence factors of $V$. cholerae. It turns out that $V$. cholerae is an excellent model for studying bacterial colonization and effects of toxin on host cells (Levine and Kaper, 1996). The bacterial infection commences with ingestion of seafood or drinking water contaminated with pathogenic $V$. cholerae. If the bacterium successfully penetrates the acid barrier of the stomach through various mechanisms such as acid tolerance response, it may pass through the pylorus and initiate a series of colonization and infective reactions (Levine and Kaper, 1996). The single flagellum may contribute to its virulence by aiding the bacterium to arrive at mucosa. There is evidence that flagellum-free mutant strains are much less virulent than their motile parental strains (Salyers and Whitt, 2002). The filamentous pili that form bundles at one end of $V$. cholerae are designated as Tcp pili (toxin coregulated pili) for the genes encoding pili are regulated similarly to genes encoding cholera toxin. Among the 15 genes encoding Tcp pili, 14 are clustered on what is now called a pathogenicity island (Karaolis et al., 1998). The accessory colonization factor (acf) genes are also located on this pathogenicity island, which have been suggested encoding an adhesin. Some research also indicated that Tcp pili may serve as a receptor for the bacteriophage that introduced the subunits of cholera toxin. Therefore, Tcp pili play an important part in the virulence evolution in pathogenic V. cholerae (Salyers and Whitt, 2002). The virulence of cholera toxin (CTX) has never been questioned since its discovery. Naturally occurring strains or ctx-free mutants of $V$. cholerae that do not produce CTX could not cause cholera in human volunteers. Due to the presence of other toxins, such strains may however cause milder diarrhea, cholera toxin is an A-B ADP-ribosylating toxin containing one A (enzymatic) subunit and B (binding) subunit (Levine and Kaper, 1996). Simply, CTX toxin catalyses the transfer of the ADP-ribose moiety of NAD to a specific arginine residue in the Gs $\alpha$ protein, resulting in the activation of adenylate cyclase and subsequent increase in intracellular levels of cAMP. Then cAMP activates a cAMP-dependent protein kinase, leading to protein phosphorylation, alteration of ion transport and ultimately severe diarrhea (Levine and Kaper, 1996). Recent study on the genome sequence of $V$. cholerae concludes that ctx genes actually came from a virulent filamentous phage CTX (Karaolis et al., 
1998). In addition to notorious CTX toxin, $V$. cholerae may produce other enterotoxins. ZOT toxin (zonula occludens toxin) is one of them. ZOT toxin affects the structure of the tight junctions, allow contents of the lumen to diffuse into underlying tissue and disrupt the ion balance and thereby cause diarrhea. And zot gene has been found to lie immediately upstream of ctxA/B operon on the CTX phage (Salyers and Whitt, 2002). ACE toxin (accessory cholera enterotoxin) is a newly discovered toxin, whose role in human disease is still unclear. But it does cause fluid accumulation in rabbit ideal loop model, which is a trait for many enterotoxins. Interestingly enough, ace gene is also located closely linked to zot (Karaolis et al., 1998; Salyers and Whitt, 2002). It seems that almost all major virulence genes are located close to each other on a CTX phage, which has been "raptured" and integrated into V. cholerae genome. Besides all the major toxins mentioned, there are other toxins that have been identified: haemolysin/cytolysin, shiga-like toxin, heat-stable enterotoxin, new cholera toxin and sodium-channel inhibitor, to name a few (Levine and Kaper, 1996).

V. cholerae is the type species of genus Vibrio. It is a small short or curved rod, 1.4 to $2.6 \mu \mathrm{m}$ in length. Distinct from other halophilic vibrios, $V$. cholerae grows in a complex medium without added salt, though its growth only reaches 50 to $80 \%$ of optimal level. High salinity of $8 \% \mathrm{NaCl}$ in the medium will inhibit its growth completely. Preferring alkaline conditions, this bacterium can grow quite well in conditions where $\mathrm{pH}$ is as high as 10 (Bradford et al., 1994). Overnight grown colonies of $V$. cholerae on TCBS agar plates are generally yellow due to sucrose fermentation, a characteristic different from the closest cousin, V. minicus (Farmer III and Hickman-Brenner, 1992). The colonies are typically big (3-4 $\mathrm{mm}$ in diameter), smooth, circular, glistering and a little bit fattened (Farmer III and Hickman-Brenner, 1992). Visible growth at $42^{\circ} \mathrm{C}$ is recorded though its optimal growth temperature is 35 to $37^{\circ} \mathrm{C}$. However, V. cholerae can be killed by heat at $60^{\circ} \mathrm{C}$ for 10 minutes. This is the reason that thorough cooking is a simple and sufficient method to eradicate $V$. cholerae infection. Low temperature at $4^{\circ} \mathrm{C}$ is often used as an inducer for its entry to VBNC state. Very sensitive to vibriostatic agent, the bacterial growth can be stopped in the presence of $10 \mu \mathrm{g} / \mathrm{ml}$ of O/129 (Sakazaki, 1989).

Historically, $V$. cholerae was divided into subgroups and there was controversy as to the classification of $V$. cholerae $\mathrm{O} 1$ and $V$. cholerae non-O1. Later on, 16S rDNA, numerical taxonomy and DNA/DNA hybridization have all supported the hypothesis that $V$. cholerae, both $\mathrm{O} 1$ and non-O1, represents a single species. And isolates of environmental and clinical sources are identical in terms of 5S rDNA sequence (Colwell et al., 1989). In the past, it was generally accepted that highly adapted $V$. cholerae $\mathrm{O} 1$ is able to exist for only very short period of time outside human intestine. But the accumulated evidence shows that $V$. cholerae is actually an autochthonous inhabitant of brackish water and estuarine system (Colwell et al., 1989). With initiation of a series of genetic and physiological changes, V. cholerae displays dynamic adaptations to the changes in the environmental parameters, including low nutrient concentration, $\mathrm{pH}$ in the range of 7 to 8 , fluctuating temperatures and exposure to UV via sunlight. It may be able to persist in the natural environment or to colonize plants or animals, which facilitates its survival during inter-epidemic periods (Islam et al., 1996). The isolation of $V$. cholerae O1 from foodstuffs such as sewage-contaminated vegetables and fruits has been reported, suggesting that the bacterium can survive in soil and sewage for an extended period of time. Fish and shellfish, incriminated in cholera outbreak, are not only contaminated with $V$. cholerae on the surface but also in their intestinal tracts or guts, both of which may act as reservoirs for the bacteria (Colwell et al., 1989; Madigan et al., 2003a; Madigan et al., 2003b; Madigan et al., 2003c; Madigan et al., 2003d; Madigan et al., 2003e; Madigan et al., 2003f).

Among the various environmental parameters that are important determinants of ecology of $V$. cholerae, salinity and temperature relationships are the first factor that deserves special attention. A nice correlation between $V$. cholerae isolated from natural environment and salinity level was established, with greater frequency of isolations at sites of salinities between 0.2 to $2 \%$. The effect of temperature was more obvious: isolations were more frequent and readily obtained when the water temperature was greater than $17^{\circ} \mathrm{C}$ (Colwell et al., 1981). This finding was also supported by Hood and his co-workers, who reported that a calculated salinity of $1.8 \%$ and temperatures between 20 and $35^{\circ} \mathrm{C}$ were optimal for recovering $V$. cholerae from water, oyster, blue crabs and sediment samples in Florida (Hood et al., 1983). The constantly changing conditions in tidal estuaries suggest that $V$. cholerae may adapt to a wide range of saline and temperature conditions in natural habitats.

The ability to associate with specific surfaces in vicinity also exerts some influence on survival chances in the natural environment. Adherence to chitin, the principal component of crustacean shells, is of great interests to many researchers. Some experiments have proven that chitin-absorbed $V$. cholerae was able to survive the very acidic conditions suggesting that such adherent organism may pass through the gastric acid barrier in human intestine (Colwell et al., 1989). In the natural environment where nutrients are depleted, $V$. cholerae tends to adhere to inert particles over chitinaceous surface to seek an ecological advantage. For instance, the attachment can mediate a transport of $V$. cholerae to sediment where it has a better chance to contact with organic particles than in water column (Hood and Ness, 1982). Apart from using chitinaceous particle as a vehicle, V. cholerae can utilize chitin as nutrients in time of food-depletion (Islam et al., 1996). The attachment to copepods is a well-recorded phenomenon. (Huq, 1981) studied the role of copepods on 
survival and multiplication of $V$. cholerae in microcosms and found that the organism survived longer and multiplied in the presence of copepods (Colwell et al., 1981). His research was further supported by Amako (1987) who observed that at low temperature $\left(0^{\circ} \mathrm{C}\right) \mathrm{V}$. cholerae attached to copepods survived more than one week, compared with less than one day without copepods (Islam et al., 1996).

Aquatic flora can also serve as reservoirs for $V$. cholerae. The marine algae produce a number of extracellular products which contain peptides, amides and nitrogen which explains why the amino-acid requiring bacteria, including $V$. cholerae are predominant on algal surfaces. With the secretive products from algae, the $V$. cholerae would be able to persist at least several months necessary to span the inter-epidemic period (Islam et al., 1996). The peak incidence of cholera in endemic areas of Bangladesh occurs together with the bloom of the blue-green algae in the natural aquatic environments, which is also an evidence to support the above findings (Islam, 1994; Islam and Bateman, 1994).

The most profound challenge to concepts concerning $V$. cholerae ecology comes from Colwell's studies, which proposed that it possesses the ability to enter a state of dormancy in response to nutrient deprivation, elevated salinity and/or reduced temperature (Colwell et al., 1994). Under the oligotrophic environments, $V$. cholerae produces its progeny cells significantly decreased in cellular size. Morphology also alters from typical bacillus to a coccoid shape with reduction of macro-molecules biosynthesis (Gauthier, 2000). As far as osmolarity is concerned, it should be noted that osmotic up-shift drastically inhibits the transport of carbohydrates and amino acids and thus may induce VBNC response to the bacterium through nutrient starvation (Roszak and Colwell, 1987). And again, living organisms have a protective effect on microorganisms in various environments. The association of $V$. cholerae to zooplankton (mainly copepods) in seawater has been proven to lower their entry to VBNC state and protect them against $\mathrm{Al}$ and chlorine treatments (Chowdhury et al., 1997).

A variety of environmental parameters may induce or favor the nonculturable responses in $V$. cholerae. In compliance with the universal law of simplicity and economy, $V$. cholerae in natural environments uses the VBNC responses to cope with encountered multistress. However, the public health significance of VBNC $V$. cholerae should never be overlooked. Cells of $V$. cholerae in VBNC state may still be capable of causing human cholera (Oliver, 2000). This finding supported the hypothesis that cells of VBNC $V$. cholerae are able to resuscitate to culturable and infectious state by following human passage. The PCR amplification of the CTX operon from VBNC cells of $V$. cholerae also enforces the concept that failure to culture $V$. cholerae from environmental or clinical samples does not prove the absolute absence of the bacterium (Huq et al., 2000). Therefore, the extensive studies in the past decades are sufficient to conclude that VBNC $V$. cholerae cannot be readily considered "dead" but rather need to be viewed as a potential public health threat.

\subsection{The Climate Links with Vibrio Diseases}

Cholera, one of the most noticeable diseases caused by $V$. cholerae displays a very clear seasonal pattern of epidemics. Cholera epidemic peaked during November to January with a second, small peak during May and June in India. This pattern has been repeated at different cholera epidemic areas in history. It is a pity that no satisfactory explanation has been put forward to explain the pattern of cholera so far (Islam et al., 1996). In addition, as mentioned already, temperature-induced phytoplankton blooms have been found to link with epidemic in certain regions of the world (Islam, 1994; Islam and Bateman, 1994). The climate-linked temperature changes have a remarkable effect on the incidence of vibrios in the natural environment. The climate warming affects the host-pathogen interaction by increasing pathogen development rates and transmissions by relaxing over-wintering restrictions on pathogen life cycle and by modifying host susceptibility to pathogen infections (Harvell et al., 2002). For example, the El Nino-induced weather change is believed to produce higher level of contamination in shellfish, which resulted in 250 cases of $V$. parahaemolyticus infections in humans in Northwest of USA in 1997 (Tamplin, 2001). And the wide presence of $V$. vulnificus in oyster meat and sediments correlates significantly with the periodicity of human vibrio infection in Gulf of Mexico (Jackson et al., 1997).

Besides human diseases, a dramatic global increase in the severity of coral bleacing in 1997 to 1998 is coincident with high El Nino temperatures. This coral bleaching is geographically extensive and caused great mortality. The bacterial pathogen of coral bleaching, V. shiloi, is temperature sensitive and grows well at the temperatures close to host optima (Kushmaro et al., 1998). V. fluvialis and V. furnissi can also quickly settle on coral tissue and begin to decompose (Lowrie and Borneman, 1999). Growth rates of marine bacteria are positively correlates with temperature in a certain range. Therefore, the increase in bacterial growth and multiplication due to the warmer temperature will have a more severe threat to coral species. Links between climate change and vibrio disease will contribute to hazards of public health and marine life in a profound way. More work still remains to be done to establish appropriate models that elucidate the relationship between Vibrio species and climate changes, thereby predicting possible outbreak of diseases such as cholera or coral bleaching.

\subsection{Vibrio Species and Wildlife}

Previous studies proved that $V$. cholerae non-O1 is much easier to isolate than $\mathrm{O} 1$ group from the environment and indeed is much more frequently isolated. And non-O1 group is not common from clinical sources (Lewin, 1996). Non-aquatic animals as reservoirs of $V$. cholerae were 
reported in early 1980s. A study in UK cultured V. cholerae non $\mathrm{O} 1$ from $6 \%$ of gulls sampled and from two mute swans (Lee et al., 1982). V. cholerae non O1 was also isolated from farmed ducks in Denmark (Bisgaard and Kristensen, 1975). Ogg and his co-worked isolated both O1 group and non-O1 group of $V$. cholerae from feces of 20 species of aquatic birds in Colorado. Two of the species, great blue heron and ring-billed gull harbored $\mathrm{O} 1$ vibrios. The researchers also suggested that aquatic birds may serve as carriers and disseminate $V$. cholera through droppings over a wide area (Ogg et al., 1989). The harboring of V. cholerae in some aquatic birds seems to be a reflection of diet which is predominantly seafood or drinking water contamination.

Bacterial disease in birds, especially poultry can bring great economic losses. Vibrio species have been listed as one of the bacterial pathogens in poultry. For instance, $V$. cholerae non-O1 has been isolated from the liver of dead goose, from nasal cavities of apparently healthy ducks and from tissues of ducks with septicemia (Barnes, 1997). V. mestchnikovii was isolated and identified to be the causative agents of diseased domesticated ducks, muscovy ducks and geeses in Germany (Hinz et al., 1999). It is also thought to produce sub-acute hemorrhagic enteritis in water fowls (Lowrie and Borneman, 1999). V. parahaemolytics, most commonly associated with sediments and zooplankton, can cause enteritis in avian species like myhahs, canaries, parakeets and finches (Lowrie and Borneman, 1999). The devastating high mortalities of birds and fish in Salton Sea, California in 1996 were finally confirmed to be caused by Vibrio species infection. Researchers believed that consumption of fish sickened by $V$. alginolyticus was the main infection passage in fisheating birds (http://www.desertusa.com/salton/salton.html). Another explanation for large die-offs of migratory birds in Salton Sea sounds a little bit "indirect". The infection of Vibrio species in fish lead to lesions, swelling of body cavity and major fatal changes in the internal organs, which might triggered the germination of botulism bacterial spores followed by secretion of toxin in the fish. If the birds consumed those sick fish, it was very likely that birds would be poisoned by deadly dosage of botulism present or infected with botulism bacteria which later caused avian cholera in birds (Kaiser, 1999). The relationship between bird health and Vibrio species, either as carriers or victims, calls for more attention and further study, for the sake of public health and bird protection.

\section{Antibiotic Resistance and the Plas- mid Profile}

The rapid spread of antibiotic resistance in bacteria, especially bacterial pathogens, is an increasingly serious problem to our society. High levels of antibiotic resistance in microorganisms in both natural and clinical environment are the direct consequence of indiscriminate use of antibiotic drugs in humans and veterinary medicine (Andersen et al.,
1994). Urban effluent which may contain various antibiotic resistant bacteria or a range of antibiotics is discharged into natural environment with no restriction currently. River waters, receiving sewage, are the main receptor for those pollutants. As rivers are the major water sources for human and animal consumption, this pollution may contribute to the maintenance or even spread of bacteria with antibiotic resistance (Goñi-Urriza et al., 2000). Sea is where all the river waters flow to, which is also the final destination of those antibiotic resistant bacteria or antibiotics. Several studies have focused on the incidences of antibiotic resistant bacteria in marine environments like sediments, coastal canal water and ocean water (Andersen et al., 1994). Vibrio species, part of natural marine environment, are at no exception to be exposed to antibiotics. Since some species come from medical sources, where antibiotics are most frequently administered, investigation on their antibiotic resistance and mechanisms is of special significance. The extensive study on antibiotic resistance in bacteria has also led to an increasing interest in the research of plasmid-medicated transfer of drug resistance, not only in hospital environment, but also in natural environment (Sandaa and Enger, 1994). Many papers have been published on the antibiotic resistance mediated by Resistance (R) plasmids in marine environment (Sizemore and Colwell, 1977; Baya et al., 1986). Those Gram negative marine bacteria are capable of receiving plasmids by conjugal gene transfer or other means.

Vibrio species are usually susceptible to tetracycline, chloramphenicol, the aminoglycosides and nalidixic acid, but susceptibility to other antibiotics may vary according to species or strains. For instance, many strains of halophilic species including V. parahaemolyticus, V. alginolyticus, V. fluvialis, V. furnissii, V. damsela and V. metschinikovii are resistant to ampicillin and $\beta$-lactase production in these species was reported. However, most strains of $V$. vulnificus and $V$. hollisae are susceptible to ampicillin. For these halophilic strains, the resistance is more likely to be intrinsic rather than plasmid-mediated (Sakazaki, 1989). In the past, $V$. cholerae $\mathrm{O} 1$ was generally susceptible to tetracycline, the choice of medicine for cholera treatment. As a result of extensive use of tetracycline and chloramphenicol drugs, plasmid-mediated resistance to a wide range of antibiotics in $V$. cholerae $\mathrm{O} 1$ has been found in Tanzania and Bangladesh (Sakazaki, 1989). Most of the V. cholerae O139 isolates from outbreak in Bangladesh and India in 1992 were recorded to be resistant to trimethoprim-sulfamethoxazole, streptomycin, furazolidone and vibriostatic agent O/129 (Bradford et al., 1994). The corresponding resistance genes were later found to be located on large conjugative elements (SXT constins) that are integrated into $\mathrm{V}$. cholerae chromosome (Hochhut et al., 2001).

Among various mobile genetic elements that may contribute to the antibiotic resistance among Vibrio species, the conjugative resistance plasmid ( $\mathrm{R}$ plasmid) received the most attention. The plasmid-encoded tetracycline resistance determinant was detected in $V$. salmonicida isolated from 
the fecally polluted sediment (Andersen et al., 1994). The conjugation of a series of multiple antibiotic resistance plasmids of different sizes took place between $V$. cholerae and Aeromonas salmonicida in seawater. And the efficiency of transfer was not temperature-dependent for bacteria (Kruse and Sorum, 1994). In Albania and Italy, V. cholerae O1 El Tor strains isolated from 1994 outbreak of cholera were characterized by their resistance to tetracycline, streptomycin, trimethoprim, sulfathiazole and O/129. The resistance genes were identified to be on a self-transferable 60 MDa conjugative plasmid (Farmer III, 1992.). In the presence of antibiotics, plasmids may utilize external selective forces for their own maintenance and their spread in Vibrio species may be proportional to the intensity of selective forces of antibiotics (Baquero et al., 1997). Under the exposure of antibiotic challenge or fluctuating environment, plasmids encoding a single type of resistance may be lost and they need to evolve to capture antibiotic resistance determinants from bacterial chromosome or other sources. The environment containing multiple antibiotics can lead to plasmid evolution towards acquisition of multiple antibiotic determinants (Baquero et al., 1997).

Besides $\mathrm{R}$ plasmids, other mobile genetic elements may also contribute to the antibiotic resistance in Vibrio species. Integrons can acquire open reading frames (gene cassettes) and convert them to functional genes. So far, more than 40 kinds of antibiotic resistance cassettes have been characterized in these structures (Koonin et al., 2001). PCR analysis of $V$. cholerae O1 strains of cholera outbreak in Vietnam clearly demonstrated the presence of Class I integrons which harbored a gene cassette encoding resistance to streptomycin and spectinomycin (Dalsgaard et al., 1999). VCRs ( $V$. cholerae repeated sequences) have been detected frequently in $V$. cholerae genome and their gene organization is identified to be similar to many well-characterized antibiotic resistance integrons. Confronted with antibiotic challenges, such structures would "capture" resistance genes through integrase mediated process and confer host strain antibiotic resistance. For the purpose of "gene capture", VCRs have been found in many Vibrio species, suggesting that this mechanism of heterologous gene acquisition is ubiquitous (Mazel et al., 1998).

Plasmids isolated from marine environment have been shown to be unrelated to numerous plasmid types previously known from clinical and environmental sources (Smalla and Sobecky, 2002). As a potential source of untapped and novel genes with possible biotechnological importance, plasmids from marine bacteria are receiving increasing attention. By means of plasmid mobilization, marine bacterial community can readily obtain plasmid-encoded trait and adapt to changing environmental conditions. The examples of plasmid-conferred advantages are protection from UV light damage, resistance to heavy metals and antibiotics, and catabolism of xenobiotic compounds (Sobecky, 1999). Research on plasmid ecology in marine sediment microbial communities showed that Vibrio species harbored different replication sequences, indicating a high diversity among bacterial population in marine sediment (Sobecky et al., 1998). Vibrio species were also reported to adapt to the oligotrophic conditions and maintained the ability to transfer plasmids. The results provided evidence that plasmid-mediated gene transfer is likely to be an important factor in determining marine bacterial community structure and function (Goodman et al., 1993). With self-transfer and mobilization features, plasmids are believed to promote the dissemination of advantageous genes throughout the naturally occurring bacterial communities in marine environment. Therefore, the study of plasmid ecology in marine Vibrio species is of importance. It contributes to a better understanding of bacterial resistance to antibiotics, heavy metals and toxic organic chemicals in the natural environment.

Environmental isolates of Vibrio species isolated from water and sediment of Mai Po Nature Reserve, Hong Kong SAR were strongly resistant to $\beta$-lactam family of antibiotics, but susceptible to tetracycline, chloramphenicol, nalidixic acid and streptomycin (Wang et al., 2004; Wang et al., 2006). In addition, $V$. cholerae MP-1 was very tolerant to high concentration of vibriostatic agent $\mathrm{O} / 129$ to $40 \mu \mathrm{g} / \mathrm{ml}$, at which the growth of $V$. aestuarianus MP-2 and $V$. vulnificus MP-2 was completely inhibited. V. cholerae MP-1 did not show any apparent growth at $15^{\circ} \mathrm{C}$, but was adapted to a much wider environmental $\mathrm{pH}$ from 5.2 to 9.2 for growth while $V$. vulnificus MP-2 was more sensitive to $\mathrm{pH}$ changes yielding the highest biomass at $\mathrm{pH} 6.2$ (Wang and $\mathrm{Gu}, 2005$ ). A. salmonicida MP-4 was surprisingly tolerant to salinity as high as $60.0 \%$ o $\mathrm{NaCl}$ and grew almost equally well as under conditions of other treatments. V. vulnificus MP-4 was the most sensitive to $\mathrm{UV}$ and $\mathrm{Fe} 3+$ treatments. A. salmonicida $\mathrm{MP}-3$ was only inhibited by $100 \mathrm{mM} \mathrm{H}_{2} \mathrm{O}_{2}$ while the other three strains did not show any growth at $10 \mathrm{mM} \mathrm{H}_{2} \mathrm{O}_{2}$. A small naturally occurring plasmid was found in $V$. cholerae MP-1 while no plasmid was detected in the other two bacteria (Zhang et al., 2007). This study suggests that Mai Po Nature Reserve harbors bacteria of unique characteristics that warrant further investigation.

\section{Nature Wetland}

The Mai Po Inner Deep Bay Ramsar site covers approximately 1500 hectares in the northwestern New Territories, Hong Kong Special Administrative Region. Consisted of extensive inter-tidal mudflats, dwarf mangroves, gei wai, reedbeds, fishponds and drainage channels, the Mai Po Inner Deep Bay Ramsar site plays an important role in supporting a wide range of wild life including migratory birds and local species (Tsim and Lock, 2002). This area was officially listed as a "Wetland of International Importance" under the Ramsar Convention in 1995. The 380-hectare Mai Po wetlands, covering mainly mangroves and gei wai, are the largest mangrove stand in Hong Kong and declared as a 
nature reserve with special habitat and visitor management (Tsim and Lock, 2002).

Mangroves are very unique inter-tidal wetland ecosystems along subtropical shores, receiving nutrient inputs from regular tidal flushing, freshwater streams and rivers. Mostly inundated by incoming tides twice a day, Mai Po mangrove habitats are characterized by fluctuating salinity, alternating aerobic and anaerobic conditions, periodic wet and dry environments, and an unstable and shifting substratum (Tam and Wong, 2000). Mangrove plants in Mai Po Nature Reserve are perennial plants belonging to diverse taxonomy but all share similar specialized morphological, structural and physiological adaptations. With salt glands, knee roots, aerial roots and viviparous reproduction, those mangrove plants survive successfully in the harsh inter-tidal environment of salinity stress and mobile substratum (Lee, 2002). Through photosynthesis, mangrove plants can produce large quantities of organic matter and provide food for small ground-dwelling benthic animals by means of leaf litter. Heterotropic bacteria and fungi also contribute to the decomposition of falling leaves and initiate a food chain that sustains other larger animals. It is believed that mangrove plants are a major source of food for marine animals in subtropics and tropics (Lee, 2002). With the abundant food resources and relatively stable water hydrology, Mai Po mangrove acts as a natural nursery to the juveniles and larvae of fishes and prawns that are of economical importance. It provides food based on its own production through photosynthesis and shelters juveniles and larvae from predators and turbid estuarine water. Apart from the protection of fish and prawn juveniles and larvae, a large number of above-ground plant structures make the habitat spatially complex. Close to the sediment surface, all these structures serve as the attachment sites for numerous sedentary animals such as oysters and barnacles. Microscopic diatoms and other unicellular algae are an additional food source to invertebrates in the mangrove. Sea-grasses are another vital component in Mai Po mangrove that support juvenile and larval stage of crustaceans and fishes (Lee, 2002). Mai Po mangrove houses not only a huge number of marine invertebrates of various classes, it is also the home to many reptile species such as snake, lizards and turtles (Tsim and Lock, 2002). As an ecologically rich area, Mai Po mangrove is the paradise for a wide range of flora and fauna.

Besides mangroves, Mai Po Nature Reserve includes other types of habitats such as gei wai, fish ponds, reedbeds and inter-tidal mudflats. Gei wai, the tidal ponds traditionally operated for aquaculture, covers about 230 hectares in Mai Po. Litter input from pond plants and the organic materials brought through the single sluice gate at high tides are the major nutrient sources. The profuse emergent vegetation provides the best nursery to shrimps and fish stocks. In winter, gei wai is drained to harvest the commercial fish and shrimps or to provide foods for hundreds of thousands of migratory birds (Tsim and Lock, 2002). The 470-hectare fish-ponds are the dominant habitats in the Inner Deep Bay Ramsar site. Each year, about 4000 tons of fresh water fish are produced from this area. Reedbeds in Mai Po Nature Reserve is the largest reedbed area in Hong Kong and Guangdong Province in P. R. China. Both reedbeds and fish ponds are valuable habitat for insects. Over 400 species of dragonfly, butterfly and moth have been recorded in or near this area. The Mai Po reedbeds also support a unique bird community. It is the only place in the world where Styan's Grasshopper Walber can be found in winter. The reed stems were used to be collected for making paper and thatching house roofs. The underground rhizomes (similar to roots) can be used as Chinese traditional medicine. As an integrated part of wetland, reedbeds function as water-cleaners by absorbing and metabolizing organic substances (http://www.ecc.org.hk/3efebinfo7.htm). The last prominent habitat in Mai Po Nature Reserve is the inter-tidal mudflat located at the delta of the Shenzhen River. Mudskipper and fiddler crabs are commonly found animals on and in the mudflat. Some crabs play a role in nutrition recycling by consuming leaf litters while others sieve out small animals and algae from mudflat sediments. And mudskippers prey on small invertebrates or microscopic algae in the mudflat. All these organisms are of paramount ecological importance to the biodiversity in Mai Po Nature Reserve (Lee, 2002). Though inter-tidal mudflat is a dynamic environment with changing salinity, its role in providing food and habitats for wildlife, especially for foraging birds, is much greater than previously believed.

Due to the fact that it supports about 49 to 68 thousand water birds in winter and more than 100 thousand birds in the entire year, Mai Po Nature Reserve has become the habitat for conservation of bird species of international and local importance. Globally threatened species such as Black-face Spoonbill, Oriental stork and Normann's Greekshank have all been recorded in Mai Po Nature Reserve (Tsim and Lock, 2002). Generally speaking, birds use inter-tidal areas for the following three main functions: 1) benthic fauna are food sources to birds; 2) birds "loaf", that is to say, to roost, preen, bathe and sleep on this area; 3 ) birds utilize mudflats for molting, which requires sufficient food resources and free from disturbance (McChesney, 1997). Mai Po Nature Reserve contains diverse habitats harboring a large variety of benthic infauna and marine invertebrates which can be consumed by migratory birds and transformed as fat and muscle tissue of the birds. The undisturbed open space of inter-tidal mudflat area in Mai Po Nature Reserve is also the ideal roosting site. Each year, hundreds of thousands of migratory birds stop at Mai Po, refuel by harvesting food and prepare for the next flights of longer distance. Located at the mid-point of East Asia-Australian Flyway, Mai Po Nature Reserve acts as an essential stop-over site and refueling ground for those migratory shorebirds (Tsim and Lock, 2002; McChesney, 1997). 
Listed as a "restricted" area under the Wild Animals Protection Ordinance, Mai Po Nature Reserve is still confronted with increasing pollutions from ex situ pressure. The booming economical developments in Shenzhen Special Economic Zone accompany the potential environmental cost. Wetlands are becoming fragmented and the wildlife is disturbed. Shallow embayments are filled to reclaim more land for development. Large quantities of domestic sewage and industrial wastewater are discharged into Inner Deep Bay area posing a threat to indigenous biodiversity. The wastes from local poultry and animal farms are simply washed into the Sham Pui River and reached the Deep Bay area without any proper treatment. The data from the regular water quality monitoring program by Hong Kong SAR Government indicated that Deep Bay area is one of the most polluted water bodies in Hong Kong (Lee et al., 1999). Heavy loads of nutrients of rich organic substances exceeds what mangrove ecosystem can deal with. And the adjacent gei wai and fish ponds have already begun to show signs of stress and deterioration. Domestic sewage containing high concentration of organic substances is the leading cause for eutrophication, which has disturbed the original ecological balance in the Mai Po Nature Reserve. Heavy metal pollution by industrial wastes is another serious problem. Three major sources of metals available to marine invertebrate presumably are seawater, sediment and diet ( $\mathrm{Lu}$ and $\mathrm{Wu}, 1993)$. It is likely that the marine invertebrates, ground-dwelling animals, fish and shrimps are under the exposure to potential accumulation of heavy metals through industrial wastewater input from Shenzhen River. Through the flow of food chain in heavy metal polluted areas of Mai Po, the toxicity will be bio-accumulated and magnified which confers potential hazards to migratory birds as advanced consumers (Lai, 2004; Lai et al., 2005). The heavy mental exposure has been reported to have negative effects on the aggressive behavior in male birds which may exert an important influence on the breeding and survival success of the birds (94). Another risk posed by environmental pollutions in Mai Po Nature Reserve is the decrease in food available to birds. As a result of water quality deterioration, there are changes in benthic species which form parts of bird's diet (Laboratory of Environmental Toxicology, 2003). Any depletion, elimination and damage of Mai Po wetlands will no doubt affect the success of bird's migration by various mechanisms such as insufficient food provision or lack of grounding place (McChesney, 1997).

In addition to the chemical and heavy metal pollution mentioned above, another aspect of domestic sewage pollutions, with perilous hazards to mankind, is the occurrence of pathogenic bacteria such as Salmonella and E. coli and infective virus (Morton and Morton, 1983). The heterotrophic bacteria brought along with domestic wastewater utilize the dissolved particulate organic matter and live freely in aquatic environment. However, through consumption of food or drinking water that has been contaminated with pathogenic bacteria or virus, human and fauna are exposed to the risk of being infected. Some may even pose life threats to public health. Other bacteria are fish pathogens which cause great economic loss in fish-farms. Therefore, the occurrence of pathogenic bacteria such as Salmonella and E. coli is a warning of the deterioration of water quality in Mai Po Nature Reserve that should receive special concerns. Moreover, besides typhoid fever caused by Salmonella typhi, there is another important public health problem-cholera, whose causative agent is Vibrio cholerae (Madigan et al., 2003a; Madigan et al., 2003b; Madigan et al., 2003c; Madigan et al., 2003d; Madigan et al., 2003e; Madigan et al., 2003f). Although there are very limited studies on the Vibrio species in Mai Po Nature Reserve so far, as common residents in aquatic environment of brackish water and rich suspended organic nutrition, Vibrio species deserve the special attention due to their potential hazards to both public and animal health.

\section{Conclusions and Future Perspec- tives}

Vibrio species can be frequently detected in a wide range of environment such as open oceans, estuaries, sediments, corals, freshwater, mollusks and fish. Though some species or strains exist as normal bacterial population in the natural marine environment, others are pathogenic or potentially pathogenic to humans, marine animals and birds. Through drinking contaminated water, consumption of contaminated seafood and direct contact with pathogen infected recreational water or wound exposure, humans are susceptible to pathogenic Vibrio species and confronted with health threats. The infection of marine animals by Vibrio species is a disaster in aquaculture, which will lead to great economic loss in mariculture farms and pose subsequent potential risks to human consumers. In addition, the coral-bleaching and large mortality of migratory birds, caused directly or indirectly by Vibrio species, have already warned both public and researchers worldwide about the risk from these species. Due to the fact that environmental isolates may uptake toxin-producing or antibiotic resistance genes through the plasmid-mediated conjugation process or integrase-facilitated "gene-capture", research including isolation, characterization, antibiotic resistance and plasmid profile in Vibrio species of environmental sources is highly desirable.

Rapid economic development and urbanization pose a serious threat to coastal ecosystem. Anthropogenic interventions through domestic sewage and industrial wastewater discharge have a great negative impact on ecosystem. The wastewater containing rich organic nutrients, heavy metals, possible bacterial pathogens and xenobiotic compounds will nourish a great number of heterotrophic bacteria including Escherichia and Salmonella and other public health threatening bacterial pathogens. Even though environmental isolates of Vibrio species may bear potential hazards to humans, marine-life and migratory birds, very little information is available on 
the isolation and characterization of this group of emerging pathogens in the changing coastal ecosystem. Therefore, it is important that studies on the Vibrio species be conducted to expand our knowledge about their presence and survival in the unique ecosystem of wetland and mangrove ecosystems.

\section{Conflict of Interest}

All authors declare that they have no conflict of interest.

\section{Ethical approval}

This article does not contain any studies with human participants or animals performed by any of the authors.

\section{Acknowledgements}

We thank Jessie Lai for the technical support of the research reported here in this laboratory.

\section{References}

Applied Biosystems. 2001. Sequencing Plasmids and PCR Products. p.3.2-3.4. In ABI Prism 3700 DNA Analyser Sequencing Chemistry Guide. Foster City, CA.

Alekshun, M.N. and Levy, S.B., 2000. Bacterial drug resistance: responses to survival threats. p.323 - 366. In G. Storz and R. Hengge-Aronis(ed.), Bacterrial Stress Responses. ASM Press, Washington D.C.

Alonso, A., Sánchez, P. and Martínez, J.L., 2001. Environmental selection of antibiotic resistance genes. Environmental Microbiology, 3, 1-9. https://doi.org/10.1046/j.1462-2920.2001.00161.x

Altschul, S.F., Madden, T.L., Schaffer, A.A., Zhang, J., Zhang, Z., Miller, W. and Lipman, D.J., 1997. Gapped BLAST and PSI-BLAST: a new generation of protein database search programs. Nucleic Acids Research, 25, 3389-3402. https://doi.org/10.1093/nar/25.17.3389

Amako, K., Shimodori, S., Imoto, T., Miake, S, and A. Umeda, 1987. Effects of chitin and its soluble derivatives on survival of Vibrio cholerae $\mathrm{O} 1$ at low temperature. Applied and Environmental Microbiology, 53, 603-605.

Andersen, S.R. and Sandaa, R.A., 1994. Distribution of tetracycline Resistance determinants among Gram-negative bacteria isolated from polluted and unpolluted marine sediments. Applied and Environmental Microbiology, 60, 908-912.

Baker, R.M., Singleton, F.L. and Hood, M.A., 1983. Effects of nutrient deprivation of Vibrio cholerae. Applied and Environmental Microbiology, 46, 930-940.

Banin, E., Khare, S.K., Naider, F. and Rosenberg, E., 2001. Prolinerich peptide from the coral pathogen Vibrio shiloi that inhibits photosynthesis of zooxanthellae. Applied and Environmental Microbiology, 67, 1536-1541. https://doi.org/10.1128/aem.67.4.1536-1541.2001

Banin, E., Israely, T., Kushmaro, A., Loya, Y., Orr, E. and Rosenberg, E., 2000. Penetration of the coral-bleaching bacterium Vibrio shiloi into Oculina patagonica. Applied and Environmental Microbiology, 66, 3031-3035.

https://www.dx.doi.org/10.1128/aem.66.7.3031-3036.2000
Baquero, F. and Blazquez, J., 1997. Evolution of antibiotic resistance. Trends in Ecology and Evolution, 12, 482-487. https://www.dx.doi.org/10.1016/S0169-5347(97)01223-8

Barancin, C.E., Smoot, J.C., Findlayand, R.H., Actis, L.A., 1998. Plasmid-mediated histamine biosynthesis in the bacterial fish pathogen Vibrio anguillarum. Plasmid, 39, 235-244. https://www.dx.doi.org/10.1006/plas.1998.1345

Baranwal, S., Dey, K., Ramamurthy, T., Nair, G.B. and Kundu, M., 2002. Role of active efflux in association with target gene mutations in fluoroquinoline resistance in clinical isolates of Vibrio cholerae. Antimicrobial Agents and Chemotherapy, 46, 2676-2678.

https://www.dx.doi.org/10.1128/AAC.46.8.26762678.2002

Barnes, A.C., Bowden, T.J., Horne, M.T and Ellis, A.E., 1999. Peroxide-inducible catalase in Aeromonas salmonicida subsp. salmonicida protects against exogenous hydrogen peroxide and killing by activated rainbow trout, Oncorhynchus mykiss L., macrophages. Microbial Pathogen, 26, 149-158. https://doi.org/10.1006/mpat.1998.0260

Barnes, H.J, 1997. Other bacterial diseases. p.289-296. In Calnek, B.W., Barnes, H.J., Beard, C.W., McDougald, L.R. and Saif, Y.M. (ed.), Disease of Poultry $\left(10^{t h}\right.$ ed). Iowa State University Press. Ames, Iowa.

Bassler, B.L., Wrightand, M., Silverman, M.R., 1994. Multiple signaling systems controlling expression of luminescence in Vibrio harveyi: sequence and function of genes encoding a second sensory pathway. Molecular Microbiology, 13, 273 286.

https://doi.org/10.1111/j.1365-2958.1994.tb00422.x

Bauer, A.W., Kirby, W.M.M., Sherris, J.C. and Turck, M., 1966. Antibiotic susceptibility testing by a standard single disk method. The American Journal of Clinical Pathology, 45, 493-496.

https://doi.org/10.1093/ajcp/45.4_ts.493

Baumann, P. and Baumann, L., 1981. The marine gram-negative eubacteria: genera Photobacterium, Beneckea, Alteromonas, Pseudomonas, and Alcaligenes. p.1352-1394. In Starr, M.P., Stolp, H., Trüper, H.G., Balows, A. and Schlegel, H.G. (ed.). The Prokaryotes: A Handbook on Habitats, Isolation and Identification of Bacteria. Spriger-Verlag, New York.

Baya, A.M., Brayton, P.R., Brown, V.L., Grimes, D.G., RussekCohen, E. and Colwell, R.R., 1986. Coincident plasmids and antimicrobial resistance in marine bacteria isolated from polluted and unpolluted Atlantic Ocean samples. Applied and Environmental Microbiology, 51, 1285-1292.

Beaber, W., Burrus, V., Hochhut, B. and Waldor, M.K., 2002. Comparison of SXT and R391, two conjugative integrating elements: definition of a genetic backbone for the mobilization of resistance determinants. Cellular and Molecular Life Science, 59, 2065-2070. https://doi.org/10.1007/s000180200006

Benson, H.J, 1998. Antimicrobial sensitivity testing: the KirbyBauer Method. p.139-141. In Microbiological Applications: Laboratory Manual in General Microbiology (7th ed.) McGraw Hill, Boston, MA.

Benson, H.J, 2002. Appendix A. p.432. In Microbiological Applications: Laboratory Manual in General Microbiology (8th ed.) McGraw Hill, Boston, MA. 
Biosca, E.G., Oliver, J.D. and Amaro, C., 1996. Phenotypic characterization of Vibrio vulnificus biotype 2, a lipopolysaccharidebased homogeneous O-serogroup within Vibrio vulnificus. Applied and Environmental Microbiology, 62, 918-927.

Bisgaard, M. and Kristensen, K.K., 1975. Isolation, characterization and public health aspects of Vibrio cholerae NAG isolated from a Danish duck farm. Avian Pathology, 4, 271 276. https://doi.org/10.1080/03079457509353875

Bradford, A.K., Bopp, C.A. and Wells, J.G., 1994. Isolation and identification of Vibrio cholerae $\mathrm{O} 1$ from fecal specimens. p.3-25. In Wachsmuth, I.K., Blake, P.A. and Olsvik, O. (ed.), Vibrio cholerae and Cholera: Molecular to Global Perspectives. ASM Press, Washington D.C.

Bryan, P.J., Steffan, R.J., DePaola, A., Foster, J.W. and Bej, A.K., 1999. Adaptive response to cold temperature in Vibrio vulnificus. Current Microbiology, 38, 168-175. https://doi.org/10.1007/PL00006782

Byrd, J.J, 2000. Morphological changes leading to the nonculturable state. p.7-18. In Colwell, R. R. and Grimes, D. J. (ed), Nonculturable Microorganisms in the Environment. ASM Press, Washington D.C. https://doi.org/10.1007/978-1-4757-0271-2_2

Carroll, J.A., Mateescu, M.C., Chava, K., Colwell, R.R. and Bej, A.K, 2001. Response and tolerance of toxigenic Vibrio cholerae $\mathrm{O} 1$ to cold temperature. Antonie van Leeuwenhoek, 79, 377-384. https://doi.org/10.1023/A:1012004725373

Castro, D., Romalde, J.L., Magarinos, J.V.B., Luque, A. and Borrego, J.J., 1997. Intraspecific characterization of Vibrio tapetis strains by use of pulsed-field gel electrophoresis, ribotyping, and plasmid profiling. Applied and Environmental Microbiology, 63, 1449-1452.

Che, R.G.O, 1999. Concentrations of 7 heavy metals in sediments and mangrove root samples from Mai Po, Hong Kong. Marine Pollution Bulletin, 39, 269-279. https://doi.org/10.1016/S0025-326X(99)00056-9

Chiang, S.L. and Mekalanos, J.J., 1999. Horizontal gene transfer in the emergence of virulent Vibrio cholerae. p.156-169. In Rosenberg, E. (ed), Microbial Ecology and Infectious Disease. ASM Press, Washington D.C.

Chowdhury, M.A., Huq, A., Xu, B., Madeira, F.J. and Colwell, R.R., 1997. Effect of alum on free-living and copepodassociated Vibrio cholerae O1 and O139. Applied and Environmental Microbiology, 63, 3323-3326.

Claus, G.W, 1989a. Antibiotic evaluation by the Kirby-Bauer Method. p.405-412. In Understanding Microbes: A Laboratory Textbook for Microbiology. W.H. Freeman Company, New York.

Claus, G.W, 1989b. Effects of ultraviolet radiation on DNA, cells viability, and mutation frequency. In Understanding Microbes: ALaboratory Textbook for Microbiology, p.333-341. W.H. Freeman, New York.

Collee, J.G., Duguid, J.P., Fraser, A.G. and Marmion, B.P., 1989. Vibrio: Aeromonas: Plesiomonas: Spirillum: Campylobactor. p.505-511. In Practical Medical Microbiology (13th ed). Churchill Livingstone, London.

Collins, C.H., Lyne, P.M. and Grange, J.M., 1995. Vibrios, Aeromonas and Pleisomonas. p.250-258. In Collins and Lyne's Microbiological Methods. Butterworth-Heineman, Oxford, U.K.
Colmer, J.A., Fralick, J.A. and Hamood, A.N., 1998. Isolation and characterization of a putative multidrug resistance pump from Vibrio cholerae. Molecular Microbiology, 27, 63-72. https://doi.org/10.1046/j.1365-2958.1998.00657.x

Colwell, R.R. and Huq, A., 1994. Vibrios in the environment: viable but nonculturable Vibrio cholerae. p.117-133. In Wachsmuth, I.K., Blake, P.A. and Olsvik, O. (ed.), Vibrio cholerae and Cholera: Molecular to Global Perspectives. ASM Press, Washington D.C. https://doi.org/10.1128/9781555818364.ch9

Colwell, R.R. and Spira, W.M., 1989. The ecology of Vibrio cholerae. p.107-127. In Barua, D. and Greenberg III, W.B. (ed.), Cholera. Plenum Medical Book Company, New York and London.

Colwell, R.R., Seidler, R.J., Kaper, J., Joseph, S.W., Garges, S., Lockman, H., Maneval, D., Bradford, H., Remmers, R.N., Huq, I. and Huq, A., 1981. Occurrence of Vibrio cholerae serotype $\mathrm{O} 1$ in Maryland and Louisiana estuaries. Applied and Environmental Microbiology, 41, 555-558.

Cook, G.C, 1996. Management of cholera: the vital role of rehydration. p.55-93. In Drasar, B.S. and Forrest, B.D. (ed.), Cholera and the Ecology of Vibrio choleae. Chapman \& Hall, London. https://doi.org/10.1007/978-94-009-1515-2_3

Couturier, M., Bex, F., Bergquist, P.L. and Maas, W.K., 1988. Identification and classification of bacterial plasmids. Microbiological Reviews, 52, 375-395.

Crosa, J.H., Tolmasky, M.E., Actis, L.A. and Falkow, S., 1994. Plasmids. p.365-386. In Gerhardt, P., Murray, R. G.E., Wood, W.S. and Krieg, N.R. (ed.). Methods for General and Molecular Bacteriology. ASM Press, Washington D.C.

Dalsgaard, A., Forslund, A., Tam, N.V., Vinh, D.X. and Cam, P.D., 1999. Cholera in Vietnam: changes in genotypes and emergence of class I integrons containing aminoglycoside resistance gene cassettes in Vibrio cholerae O1 strains isolated from 1979 to 1996. Journal of Clinical Microbiology, 37, 734-741.

Davis, J. and Amabile-Cuevas, C.F., 2003. The rise of antibiotic resistance. p.1-7. In Amabile-Cuevas, C.F. (ed), Multiple Drug Resistant Bacteria. Horizon Scientific Press, Wiltshire, UK.

Demers, S., Belzile, C., Lean, D.R.S., Mostajir, B., Roy, S., Mora, S.D., Bird, D., Gosselin, M., Chanut, J.P. and Levasseur, M., 1998. An experimental tool to study the effects of ultraviolet radiations on planktonic communities: a mesocosm approach. Environmental Technology, 19, 667-682. https://doi.org/10.1080/09593331908616723

DePaola, A., Ulaszek, J., Kaysner, C.A., Tenge, B.J., Nordstrom, J.L., Wells, J., Puhr, N. and Gendel, S.M., 2003. Molecular, serological, and virulence characteristics of Vibrio parahaemolyticus isolated from environmental, food, and clinical sources in north America and Asia. Applied and Environmental Microbiology, 69, 3999-4005. https://doi.org/10.1128/AEM.69.7.3999-4005.2003

DePaola, A., Motes, M.L., Chan, A.M. and Suttle, C.A., 1998. Phages infecting Vibrio vulnificus are abundant and diverse in oysters (Crassostrea virginica) collected from the Gulf of Mexico. Applied and Environmental Microbiology, 64, 346-351.

Dromigny, J.A., Alson, O.R., Rajaonatahina, D., Migliani, R., Ranjalahy, J. and Mauclere, P., 2002. Emergence and rapid 
spread of tetracycline-resistant Vibrio cholerae strains, Madagascar. Emerging Infectious Disease, 8, 336-338. https://doi.org/10.3201/eid0803.010258

Dumontet, S., Krovacek, K., Baloda, B., Grottoli, R., Pasquale, V. and Vanucci, S., 1996. Ecological relationship between Aeromonas and Vibrio spp. and planktonic copepods in the costal marine environment in southern Italy. Comparative Immunology, Microbiology and Infectious Disease, 19, 245253. https://doi.org/10.1016/0147-9571(96)00012-4

Dumontet, S., Krovacek, K., Svenson, S.B., Pasquale, V., Baloda, S.B. and Figliuolo, G., 2000. Prevalence and diversity of Aeromonas and Vibrio spp. in coastal waters in southern Italy. Comparative Immunology, Microbiology and Infectious Disease, 23, 53-72. https://doi.org/10.1016/S0147-9571(99)00059-4

Dziejman, M., Balon, E., Boyd, D., Fraser, C.M., Heidelberg, J.F. and Meckalanos, J.J., 2002. Comparative genomic analysis of Vibrio cholerae: genes that correlate with cholera endemic and pandemic disease. Proceedings of the National Academy of Sciences USA, 99, 1556-1561. https://doi.org/10.1073/pnas.042667999

Ehrlich, H.L, 2002. Geomicrobiology of iron. p.345-429. In Geomicrobiology (4th ed). Marcel Dekker, New York.

El-Mansi, M., Anderson, K.J., Inche, C.A., Knowles, L.K. and Platt, D.J., 2000. Isolation and curing of the Klebsiella pneumoniae large indigenous plasmid using sodium dodecyl sulphate. Research in Microbiology, 151, 201-208. https://doi.org/10.1016/S0923-2508(00)00140-6

Falbo, V., Carattoli, A., Tosini, F., Pezzella, C., Dionisi, A.M. and Luzzi, I, 1999. Antibiotic resistance conferred by a conjugative plasmid and a class I integron in Vibrio cholerae $\mathrm{O} 1$ El Tor strains isolated in Albania and Italy. Antimicrobial Agents and Chemotherapy, 43, 693-696.

Fan, Y.Z., Wang, Y.Y., Qian, P.Y. and Gu, J.D., 2004. Optimization of phthalic acid batch biodegradation and the use of modified Richards model for modeling degradation. International Biodeterioration and Biodegradation, 53, 57-63. https://doi.org/10.1016/j.ibiod.2003.10.001

Farmer, J.J. III, 1992. The family Vibrionaceae.p.2398-2952. In Balows, A., Truper, H.G., Dworkin, M. and Harder, W. (ed.), The Prokaryotes: a Handbook on the Biology of Bacteria: Ecophysiology, Isolation, Identification, Applications. Springer-Verlag, New York.

Farmer, J.J. III and Hickman-Brenner, F.W., 1992. The genera Vibrio and Photobacterium. p.2952-3005. In Balows, A., Truper, H. G., Dworkin, M. and Harder, W. (ed.), The Prokaryotes: a Handbook on the Biology of Bacteria: Ecophysiology, Isolation, Identification, Applications. Springer-Verlag, New York.

Faruque, S.M., Albert, M.J. and Mekalanos, J.J., 1998. Epidemiology, genetics, and ecology of toxigenic Vibrio cholerae. Microbiology and Molecular Biology Review, 62, 1301-1314.

Figurski, D, 2003. Personal communication.

French, G.L., Woo, M.L., Hui, Y.W. and Chan, K.Y., 1989. Antimicrobial susceptibility of halophilic vibrios. Journal of Antimicrobial Chemotherapy, 24, 183-194. https://doi.org/10.1093/jac/24.2.183

Galinski, E.A. and Sauer, T., 1998. Production and application of natural stabilizing compounds from halotolerant bacteria. p.201-205. In Gal Y.L. and Halvorson, H.O. (ed.), New Developments in Marine Biotechnology. Plenum Press. New York \& London.

https://doi.org/10.1007/978-1-4757-5983-9_42

Gauthier, M.J, 2000. Environmental parameters associated with the viable but nonculturable state. p.87-112. In Colwell, R.R. and Grimes, D.J. (ed.), Nonculturable Microorganisms in the Environment. ASM Press, Washington D.C. https://doi.org/10.1007/978-1-4757-0271-2_7

Giles, J.S., Hariharan, H. and Heaney, S.B., 1995. The plasmid profiles of fish pathogenic isolates of Aeromonas salmonicida, Vibrio anguillarum, and Vibrio ordalii from the Atlantic and Pacific coasts of Canada. Canadian Journal of Microbiology, 41, 209-216.

https://doi.org/10.1139/m95-029

Goñi-Urriza, M., Capdepuy, M., Arpin, C., Raymond, N., Caumetteand, P., Quentin, C., 2000. Impact of an urban effluent on antibiotic resistance of riverine Enterobacteriaceae and Aeromonas spp. Applied and Environmental Microbiology, 66, 125-132. https://doi.org/10.1139/m95-029

Goodman, A.E., Hild, E., Marshall, K.C. and Hermansson, M., 1993. Conjugative plasmid transfer between bacteria under simulated marine oligotrophic conditions. Applied and Environmental Microbiology, 59, 1035-1040.

Gu, J.D. and Mitchell, R., 2001. Antagonism of bacterial extracellular metabolites to the freshwater fouling zebra mussels, Dreissena polymorpha. The Journal of Microbiology, 39, 133-138.

Gu, J.D. and Mitchell, R., 2002. Indigenous microflora and opportunistic pathogens of the freshwater zebra mussels, Dreissena polymorpha. Hydrobiologia, 474, 81-90. https://doi.org/10.1023/A:1016517107473

Guiney, D.G. and Landa, E., 1989. Conjugative transfer of Inc plasmids. p.27-56. In Thomas, C.M. (ed.). Promiscuous Plasmids of Gram-Negative Bacteria. Academic Press, London.

Hameed, A.S.S., Rahaman, K.H., Alagan, A. and Yoganandhan, K., 2003. Antibiotic resistance in bacteria isolated from hatchery-reared larvae and post-larvae of Macrobrachium rosenbergii. Aquaculture, 217, 39-48.

https://doi.org/10.1016/S0044-8486(02)00298-3

Harvell, C.D., Mitchell, C.E., Ward, J.R., Altizer, S., Dobson, A.P., Ostfeld, R.S. and Samuel, M.D., 2002. Climate warming and disease risks for terrestrial and marine Biota. Science, 296, 2158-2162.

https://doi.org/10.1126/science.1063699

Hazen, T.H., Pan, L., Gu, J.D. and Sobecky, P.A., 2010. The contribution of mobile genetic elements to the evolution and ecology of Vibrios. FEMS Microbiology Ecology, 74, 485499. https://doi.org/10.1111/j.1574-6941.2010.00937.x

Heidelberg, J.F., Eisen, J.A., Nelson, W.C., Clayton, R.A., Gwinn, M.L., Dodson, R.J., Haft, D.H., Hickey, E.K., Peterson, J.D., Umayam, L., Gill, S.R., Nelson, K.E., Read, T.D., Tettelin, H., Richardson, D., Ermolaeva, M.D., Vamathevan, J., Bass, S., Qin, H.Y., Dragoi, I., Sellers, P., Mcdonald, L., Utterback, T., Fleishmann, R.D., Nierman, W.C., White, O., Salzberg, S.L., Smith, H.O., Colwell, R.R., Mekalanos, J.J., Venter, J.C. and Fraser, C.M., 2000. DNA sequence of both chromosomes of the cholera pathogen Vibrio cholerae. 
Nature, 406, 477-483.

https://doi.org/10.1038/35020000

Helinski, D.R., Toukdarian, A.E. and Novick, R.P., 1996. Replication control and other stable maintenance mechanisms of plasmids. p.2295-2324. In Neidhardt, F.C. (ed.), Escherichia coli and Salmonella typhimurium: Cellular and Molecular Biology. (2nd ed). ASM Press, Washington D.C.

Hinz, H.Z., Ryll, M. and Glunder, G., 1999. Isolation and identification of Vibrio metschnicovii from domestic ducks and geese. Zentralbl Veterinarmed, 46, 331-339. https://doi.org/10.1111/j.1439-0450.1999.tb01238.x

Hochhut, B., Lotfi, Y., Mazel, D., Faruque, S.M., Woodgate, R. and Waldor, M.K., 2001. Molecular analysis of antibiotic resistance gene clusters in Vibrio cholerae $\mathrm{O} 139$ and $\mathrm{O} 1$ SXT constins. Antimicrobial Agents and Chemotherapy, 45, 2991-3000.

https://doi.org/10.1128/AAC.45.11.2991-3000.2001

Hofer E., Reis, E.M., Quintaes, B.R., Rodrigues, D.P., Feitosa, I.S., Angelo, M.R. and Ribeiro, L.H., 2001. Vibrio cholerae resistant to 2,4-diamino-6,7-diisopropylpteridine (O/129) isolated from patients with enteritis in Ceara, Brazil. Journal of Health and Population Nutrition, 19, 39-42.

Høi, L., Larsen, J.L., Dalsgaard, I. and Dalsgaard, A., 1998. Occurrence of Vibrio vulnificus biotypes in danish marine environments. Applied and Environmental Microbiology, 64, $7-13$

Hollis, D.G., Weaver, R.E., Baker, C.N. and Thornsberry, C., 1976. Halophilic Vibrio species isolated from blood cultures. Journal of Clinical Microbiology, 3, 425-431.

Honda, T., Ni, Y., Miwatani, T., Adachi, T. and Kim, J., 1992. The thermostable direct hemolysin of Vibrio parahaemolyticus is a pore-forming toxin. Canadian Journal of Microbiology, 38, $1175-1180$ https://doi.org/10.1139/m92-192

Hood, M.A. and Ness, G.E., 1982. Survival of Vibrio cholerae and Echerichia coli in estuarine waters and sediments. Applied and Environmental Microbiology, 43, 678-684.

Hood, M.A., Ness, G.E., Rodrick, G.E. and Blake, N.J., 1983. Distribution of Vibrio cholerae in two Florida estuaries. Microbial Ecology, 9, 65-75. https://doi.org/10.1007/BF02011581

Huda, N., Lee, E.W., Chen, J., Morita, Y.J., Kuroda, T., Mizushima, T. and Tsuchiya, T., 2003. Molecular Cloning and Characterization of an ABC multidrug efflux pump, VcaM, in non-O1 Vibrio cholerae. Antimicrobial Agents and Chemotherapy, 47, 2413-2417. https://doi.org/10.1128/AAC.47.8.2413-2417.2003

Huntley, J.S., Hall, A.C., Sathyamoorthy, V. and Hall, R.H., 1993. Cation flux studies of the lesion induced in human erythrocyte membranes by the thermostable direct hemolysin of Vibrio parahaemolyticus. Infection and Immunity, 61, 4326-4332.

Huq, A., Rivera, I.N.G. and Colwell, R.R., 2000. Epidemiological significance of viable but nonculturable microorganisms. p.301-324. In Colwell, R.R. and Grimes, D.J. (ed.), Nonculturable Microorganisms in the Environment. ASM Press, Washington D.C. https://doi.org/10.1007/978-1-4757-0271-2_17

Huq, A., Alam, M., Parveen, S. and Colwell, R.R., 1992. Occurrence of resistance to vibriostatic compound O/129 in Vibrio cholerae $\mathrm{O} 1$ isolated from clinical and environmental samples in Bangladesh. Journal of Clinical Microbiology, 30, 219-221.

Ichise, N., Morita, N., Hoshino, T., Kawasaki, K., Yumoto, I. and Okuyama, H., 1999. A mechanism of resistance to hydrogen peroxide in Vibrio rumoiensis S-1. Applied and Environmental Microbiology, 65, 73-79.

Imlay, J.A., Chin, S.M. and Linn, S., 1988. Toxic DNA damage by hydrogen peroxide through the Fenton in vivo and in vitro. Science, 240, 640-642.

https://doi.org/10.1126/science.2834821

Islam, M.S, 1994. Reservoirs, seasonality and endemicity of cholera in Bangladesh: role of environment. p.9-10. In Proceedings of the Third Annual Scientific Conference of International Centre for Diarrhoeal Disease Research, Bangladesh.

Islam, M.S. and Bateman, O.M., 1994. Cholera control in developing countries. Waterlines, 12, 20-23. https://doi.org/10.3362/0262-8104.1994.019

Islam, M.S., Drasar, B.S. and Sack, R.B., 1996. Ecology of Vibrio cholerae: role of aquatic fauna and flora. p.187-227. In Drasar, B.S. and Forrest, B.D. (ed.), Cholera and the Ecology of Vibrio choleae. Chapman \& Hall. London. https://doi.org/10.1007/978-94-009-1515-2_6

Jackson, J.K., Murphree, R.L. and Tamplin, M.L., 1997. Evidence that mortality from Vibrio vulnificus infection results from single strains among heterogeneous populations in shellfish. Journal of Clinical Microbiology, 35, 2098-2101.

Jacobs, J.L. and Sundin, G.W., 2001. Effect of solar UV-B radiation on a phyllosphere bacterial community. Applied and Environmental Microbiology, 67, 5488-5496. https://doi.org/10.1128/AEM.67.12.5488-5496.2001

Janssens, E., Dauwe, T., Van Duyse, E., Beernaert, J., Pinxten, R. and Eens, M., 2003. Effects of heavy metal exposure on aggressive behavior in a small territorial songbird. Archives of Environmental Contamination and Toxicology, 45, 121127. https://doi.org/10.1007/s00244-002-0133-7

Jenkins, D.E., Schultz, J.E. and Schultz, A., 1988. Starvationinduced cross protection against heat or $\mathrm{H}_{2} \mathrm{O}_{2}$ challenge in Escherichia coli. Journal of Bacteriology, 170, 3910-3914. https://doi.org/10.1128/jb.170.9.3910-3914.1988

Jiang, S.C., Louis, V., Choopun, N., Sharma, A., Huq, A. and Colwell, R.R., 2000. Genetic diversity of Vibrio cholerae in Chesapeake Bay determined by amplified fragment length polymorphism fingerprinting. Applied and Environmental Microbiology, 66, 140-147. https://doi.org/10.1128/AEM.66.1.140-147.2000

Joseph, S.W., Colwell, R.R. and Kaper, J.B., 1982. Vibrio parahaemolyticus and related halophilic vibrios. Critical Reviews in Microbiology, 10, 77-124. https://doi.org/10.3109/10408418209113506

Joux, F., Jefferey, W.H., Lebaron. P. and Mitchell, D.L., 1999. Marine bacterial isolates display diverse responses to UVB radiation. Applied and Environmental Microbiology, 65, 3820-3827.

Kaiser, E. and Herndl,G.J., 1997. Rapid recovery of marine bacterioplankton activity after inhibition by UV Radiation in coastal waters. Applied and Environmental Microbiology, 63, 4026-4031. 
Kaiser, J, 1999. Battle over a dying sea. Science, 284, 28-30. https://doi.org/10.1126/science.284.5411.28

Karaolis, D.K.R., Johnson, J.A., Bailey, C.C., Boedeker, E.C., Kaper, J.B. and Reeves, P.R., 1998. A Vibrio cholerae pathogenicity island associated with epidemic and pandemic strains. Proceedings of the National Academy of Sciences of the United States of America, 95, 3134-3139. https://doi.org/10.1073/pnas.95.6.3134

Kariuki, S. and Hart, C.A., 2001. Global aspects of antimicrobialresistant enter bacteria. Current Opinion in Infectious Diseases, 4, 579-586. https://doi.org/10.1097/00001432-200110000-00012

Kaspar, C.W. and Tamplin, M.L., 1993. Effects of temperature and salinity on the survival of Vibrio vulnificus in seawater and shellfish. Applied and Environmental Microbiology, 59, 2425-2429.

Khamala, J.K., Mwarumba, S., Lewa, P. and Lowe, B., 2002. Vibrio cholerae $\mathrm{O} 1$ strain resistant to vibriostatic compound O/129 isolated from cholera cases in Kilifi, Kenya. East Africa Medical Journal, 79, 560.

Kim, W.S., Park, J.H., Tandianus, J.E., Ren, J., Su, P. and Dunn, N. W., 2002. A distinct physiological state of Lactococcus lactis cells that confers survival against a direct and prolonged exposure to severe stresses. FEMS Microbiology Letters, 212, 203-208. https://doi.org/10.1111/j.1574-6968.2002.tb11267.x

Kimoto, R., Funahashi, T., Yamamoto, N., Miyoshi, S., Narimatsu, S. and Yamamoto, S., 2001. Identification and characterization of the sodA genes encoding manganese superoxide dimutases in Vibrio parahaemolyticus, Vibrio minicus, and Vibrio vulnificus. Microbiology and Immunology, 45, 135142. https://doi.org/10.1111/j.1348-0421.2001.tb01281.x

Knox, J.R., Moews, P.C. and Frere, J.M., 1996. Molecular evolution of bacterial beta-lactam resistance. Chemistry and Biology, 3, 937-947. https://doi.org/10.1016/S1074-5521(96)90182-9

Koga, T. and Takumi, K., 1995. Nutrient starvation induces cross protection against heat, osmotic, or $\mathrm{H}_{2} \mathrm{O}_{2}$ challenge in Vibrio parahaemolyticus. Microbiology and Immunology, 39, 213215. https://doi.org/10.1111/j.1348-0421.1995.tb02191.x

Koo. J., DePaola, A. and Marshall, D.L., 2000. Effect of simulated gastric fluid and bile on survival of Vibrio vulnificus and Vibrio vulnificus phage. Journal of Food Protection, 63, 16651669

https://doi.org/10.4315/0362-028X-63.12.1665

Kook, H., Rhee, J.H., Lee, S.E., Kang, S.Y., Chung, S.S., Cho, K.W. and Baik, Y.H., 1999. Activation of particulate guanylyl cyclase by Vibrio vulnificus hemolysin. European Journal of Pharmacology, 365, 267-272. https://doi.org/10.1016/S0014-2999(98)00870-X

Koonin, E.V., Makarova, K.S. and Aravind, L., 2001. Horizontal gene transfer in prokaryotes: quantification and classification. Annual Review of Microbiology, 55, 709-742. https://doi.org/10.1146/annurev.micro.55.1.709

Kruse, H. and Sorum, H., 1994. Transfer of multiple drug resistance plasmids between bacteria of diverse origins in natural microenvironments. Applied and Environmental Microbiology, 60, 4015-4021.
Kushmaro, A., Rosenberg, E., Fine, M., Haim, Y.B. and Loya, Y., 1998. Effect of temperature on bleaching of the coral Oculina patagonica by Vibrio AK-1. Marine Ecology Progress Series, 171, 131-137. https://doi.org/10.3354/meps 171131

Laboratory of Environmental Toxicology, 2003. Baseline Ecological Monitoring Program for Mai Po and Inner Deep Bay Ramsar Site 2001-2002 Final Report. p.266. Department of Ecology \& Biodiversity, The University of Hong Kong, Hong Kong.

Lai, M.Y, 2004. Fractionation, mobilization and bioaccumulation of heavy metals and mineralogical characteristics of the Mai Po Inner Deep Bay mudflat. MPhil Thesis, The University of Hong Kong, Hong Kong.

Lai, M.Y., Shen, P., and Gu, J.D., 2005. Heavy metals in the benthic infauna gastropoda (Sermyla riqueti and Stenothyra devalis) of Mai Po Nature Reserve and Inner Deep Bay Ramsar Site of Hong Kong. Bulletin of Environmental Contamination and Toxicology, 74, 1065-1071. https://doi.org/10.1007/s00128-005-0689-9

Landre, J.P.B, Gavriel, A.A., Rust, R.C. and Lamb, A.J., 2000. The response of Aeromonas hydrophila to oxidative stress induced by exposure to hydrogen peroxide. Journal of Applied Microbiology, 89, 145-151. https://doi.org/10.1046/j.1365-2672.2000.01090.x

Lawrence, J. and Roth, J., 1998. Roles of horizontal transfer in bacteria in bacterial evolution. p.208-228. In Syvanen, M. and Kado, C.T. (ed.), Horizontal Gene Transfer. Chapman and Hall, New York.

Lee, J.V., Bashford, D.J., Donovan, T.J., Furniss, A.L. and West, P.A., 1982. The incidence of Vibrio cholerae in water, animals and birds in Kent, England. Journal of Applied Microbiology, 52, 281-291.

Lee, K.K., Chen, Y.L. and Liu, P.C., 1999. Hemostasis of tiger prawn Penaeus monodonaffected by Vibrio harveyi, extracellular products, and a toxic cysteine protease. Blood Cells, Molecules and Disease, 25, 180-192. https://doi.org/10.1006/bcmd.1999.0244

Lee, S.Y, 1999. Preface. p.VII. In Lee, S.Y. (ed.), The Mangrove Ecosystem of Deep Bay and Mai Po Marshes, Hong Kong. Hong Kong University Press, Hong Kong.

Lee, S. Y, 2002. Forest in the Water. Cosmos Book Ltd, Hong Kong.

Lesmana, M., Subekti, D.S., Tjaniadi, P., Simanjuntak, C. H., Punjabi, N.H., Campbell, J.R. and Oyofo, B.A., 2002. Spectrum of Vibrio species associated with acute diarrhea in North Jakarta, Indonesia. Diagnostic Microbiology and Infectious Disease, 43, 91-97. https://doi.org/10.1016/S0732-8893(02)00373-5

Levine, M.M. and Kaper, J.B., 1996. Cholera: pathogenesis and vaccine development. p.125-186. In Drasar, B.S. and Forrest, B.D. (ed.), Cholera and the Ecology of Vibrio choleae. Chapman \& Hall, London.

https://doi.org/10.1007/978-94-009-1515-2_5

Levy, S.B, 1995. Antibiotic resistance: a global perspective. p.113. In Jungkind, D.L., Mortensen, J. E., Fraimow, H.S. and Calandra, G.B. (ed), Antimicrobial Resistance: A Crisis in Health Care. Plenum Press, New York and London. https://doi.org/10.1007/978-1-4757-9203-4_1 
Levy, S.B, 1998a. The challenge of antibiotic resistance. Scientific American, 278 (3), 46-54. https://doi.org/10.1038/scientificamerican0398-46

Levy, S.B, 1998b. Antimicrobial resistance: bacteria on the defense. British Medical Journal, 317, 612-613. https://doi.org/10.1136/bmj.317.7159.612

Levy, S.B, 2001. Antibiotic resistance: consequences of inaction. Clinical Infectious Diseases, 33(suppl), 124-129. https://doi.org/10.1086/321837

Levy, S.B, 2002a. Antibiotic resistance: microbial adaptation and evolution. p.71-114. In The Antibiotic Paradox: How the Misuse of Antibiotics Destroys Their Curative Powers. Perseus Publishing, Cambridge, MA.

Levy, S.B, 2002b. Active efflux, a common mechanism for biocide and antibiotic resistance. Journal of Applied Microbiology Symposium Supplement, 92, 65-71.

Lewin, S.M, 1996. Zoological microhabitats of Vibrio cholerae. p.228-254. In Drasar, B. S. and Forrest, B.D. (ed.), Cholera and the Ecology of Vibrio choleae. Chapman \& Hall, London. https://doi.org/10.1007/978-94-009-1515-2_7

Li, J., Yie, J., Foo, R.W.T., Ling, J.M.L., Xu, H.S. and Woo, N.Y.S., 1999. Antibiotic resistance and plasmid profiles of Vibrio isolates from cultured Silver Sea Bream, Sparus sarba. Marine Pollution Bulletin, 39, 245-249. https://doi.org/10.1016/S0025-326X(99)00062-4

Lin, P., 1999. The Mai Po Nature Reserve, Hong Kong. p.256-257. In Mangrove Ecosystem in China. Science Press, New York.

Lowrie, J. and Borneman, E., 1999. A Survey of Marine Microbes. http://www.animalnetwork.com/fish2/aqfm/1999/may/features /1/default.asp

Lu, Y.M. and Wu, H.R., 1993. Study on coastal water environmental protection in the Pearl River Delta. p.139-149. In Guangdong Environmental Protection Bureau (ed.), Proceedings of the International Workshop for Development of Strategies for Pollution Control in Pearl River Delta. Guangdong Environmental Protection Bureau, Guangzhou.

Lyons, M.M., Aas, P., Pakulski, J.D., van Waasbergen, L., Miller, R.V., Mitchell, D.L. and Jefferey, W.H., 1998. DNA damage induced by ultraviolet radiation in coral-reef microbial communities. Marine Biology, 130, 537-543. https://doi.org/10.1007/s002270050274

Madigan, M.T., Martinko, J.M. and Parker, J., 2003a. Prokaryotic diversity: bacteria. p.351-444. In Brock Biology of Microorganisms (10th ed). Pearson Education Inc, New Jersey.

Madigan, M.T., Martinko, J.M. and Parker, J., 2003b. Waste water treatment, water purification and waterborne microbial diseases. p.934-949. In Brock Biology of Microorganisms (10th ed). Pearson Education Inc, New Jersey.

Madigan, M.T., Martinko, J.M. and Parker, J., 2003c. Microbial growth control. p.696. In Brock Biology of Microorganisms (10th ed). Pearson Education Inc, New Jersey.

Madigan, M.T., Martinko, J.M. and Parker, J., 2003d. Synthetic antimicrobial drugs. p.711. In Brock Biology of Microorganisms (10th ed). Pearson Education Inc, New Jersey.

Madigan, M.T., Martinko, J.M. and Parker, J., 2003e. Antimicrobial drug resistance. p.720. In Brock biology of Microorganisms (10th ed). Pearson Education Inc, New Jersey.

Madigan, M.T., Martinko, J.M. and Parker, J., 2003f. Plasmid. p.286. In Brock biology of Microorganisms (10th ed). Pearson Education Inc, New Jersey.
Marshall, J, 1995. Antimicrobial susceptibility testing. p.123-134. In Microbiology: the Clinical Laboratory Manual Series. Delmar Publishers Inc, Albany, N. Y.

Mazel, D. and Davies, J., 1999. Gene capture in Vibrio cholerae: response. Trends in Microbiology, 7, 95. https://doi.org/10.1016/S0966-842X(99)01463-8

Mazel, D., Dychinco, B., Webband, V.A., Davies, J., 1998. A distinctive class of integron in the Vibrio cholerae genome. Science, 280, 603-605. https://doi.org/10.1126/science.280.5363.605

McChesney, S, 1997. The benthic invertebrate community of the intertidal mudflat at the Mai Po Mmarshes Nature Reserve, with special reference to resources for migrant shorebirds. MPhil Thesis, The University of Hong Kong, Hong Kong.

McDougald, D., Gong, L., Srinivasan, S., Hild, E., Thompson, L. Takayama, K., Rice, S.A. and Kjelleberg, S., 2002. Defences against oxidative stress during starvation in bacteria. Antonie van Leeuwenhoek, 81, 3-13. https://doi.org/10.1023/A:1020540503200

Meinhardt, F., Wodara, C., Larsen, M. and Schickel, J., 1994. Novel approach to express a heterologous gene on Kluyveromyces lactislinear killer plasmids: expression of the bacterial aphgene from a cytoplasmic promoter fragment without in-phase fusion to the plasmid open reading frame. Plasmid, 32, 318-327. https://doi.org/10.1006/plas.1994.1071

Merrell, D.S., Bailey, C., Kaper, J.B. and Camilli, A., 2001. The Tox-R mediated organic acid tolerance reponse of Vibrio cholerae requires OmpU. Journal of Bacteriology, 183, 27462754.

https://doi.org/10.1128/JB.183.9.2746-2754.2001

Merrell, D.S., Havaand, D.L., Camilli, A., 2002. Identification of novel factors involved in colonization and acid tolerance of Vibrio cholerae. Molecular Microbiology, 43, 1471-1491. https://doi.org/10.1046/j.1365-2958.2002.02857.x

Mezrioui, N. and Oufdou, K., 1996. Abundance and antibiotic resistance of non-O1 Vibrio cholerae strains in domestic wastewater before and after treatment in stabilization ponds in an arid region (Marrakesh, Morocco). FEMS Microbiology Ecology, 21, 277-284. https://doi.org/10.1111/j.1574-6941.1996.tb00124.x

Morton, B. and Morton, J., 1983. Enclosed flats. p.206-253. In The Sea Shore Ecology of Hong Kong. Hong Kong University Press, Hong Kong.

Motes, M.L., DePaola, A., Cook, D.W., Veazey, J.E., Hunsucker, J.C., Garthright, W.E., Blodgett, R.J. and Chirtel, S.J., 1998. Influence of water temperature and salinity on Vibrio vulnificus in Northern Gulf and Atlantic Coast Oysters (Crassostrea virginica). Applied and Environmental Microbiology. 64: 1459-1465.

Mukhopadhyay, A.K., Basu, I., Bhattacharya, S.K., Bhattacharya, M.K. and Nair, G.B., 1998. Emergence of fluoroquinoline resistance in strains of Vibrio cholerae isolated from hospitalized patients with acute diarrhea in Calcutta, India. Antimicrobial Agents and Chemotherapy, 42, 206-207.

Naidu, A.J. and Yadav, M., 1997. Influence of iron, growth temperature and plasmids on siderophore production in Aeromonas hydrophila. Journal of Medical Microbiology, 46, 833-838. https://doi.org/10.1099/00222615-46-10-833 
Nath, G. and Sanyal, S.C., 1992. Emergence of Vibrio cholerae O1 resistant to vibriostatic agent. Lancet, 340, 366-367. https://doi.org/10.1016/0140-6736(92)91438-E

Nierman, W.C., Feldblyum, T.V., Laub, M.T., Paulsen, I.T., Nelson, K.E., Eisen, J., Heidelberg, J.F., Alley, M.R.K., Ohta, N., Maddock, J.R., Potocka, I., Nelson, W.C., Newton, A., Stephens, C., Phadke, N.D., Ely, B., DeBoy, R.T., Dodson, R.J., Durkin, A.S., Gwinn, M.L., Haft, D.H., Kolonay, J.F., Smit, J., Craven, M.B., Khouri, H., Shetty, J., Berry, K., Utterback, T., Tran, K., Wolf, A., Vamathevan, J., Ermolaeva, M., White, O., Salzberg, S.L., Venter, J.C., Shapiro, L. and Fraser, C.M., 2001. Complete genome sequence of Caulobacter crescentus. Proceedings of the National Academy of Sciences of the United States of America, 98, 4136-4141. https://doi.org/10.1016/0140-6736(92)91438-E

Nishibuchi, M. and Kaper, J.B., 1995. Thermostable direct hemolysin gene of Vibrio parahaemolyticus: a virulence gene acquired by a marine bacterium. Infection and Immunity, 63, 2093-2099.

Noales, E.M., Biosca, E.G. and Amaro, C., 1999. Effects of salinity and temperature on long-term survivial of the eel pathogen Vibrio vunificus Biotype 2 (serovar E). Applied and Environmental Microbiology, 65, 1117-1126.

Nordstrom, K, 1993a. Introduction. p.1. In Hardy, K.G. (ed.), Plasmids: A Practical Approach. (2nd ed). IRL Press at Oxford University Press Inc, New York.

Nordstrom, K, 1993b. Basic replicons. p.21-22. In Hardy, K.G. (ed.), Plasmids: A Practical Approach. (2nd ed). IRL Press at Oxford University Press Inc, New York.

Nystrom, T., Olsson, R.M. and Kjelleberg, S., 1992. Survival, stress resistance, and alterations in protein expression in the marine Vibrio sp. strain S14 during starvation for different individual nutrients. Applied and Environmental Microbiology, 58, 55-65.

Ogg, J.E., Ryder, R.A. and Smith, H.L., 1989. Isolation of Vibrio cholerae from aquatic birds in Colorado and Utah. Applied and Environmental Microbiology, 55, 95-99.

Oliver, J.D, 1993. Formation of Viable but Nonculturable cells. p.239-272. In Kjelleberg, S. (ed.), Starvation in Bacteria. Plenum Press, New York. https://doi.org/10.1007/978-1-4899-2439-1_11

Oliver, J.D., 2000. The public significance of viable but nonculturable bacteria. p.277-300. In Colwell, R.R. and Grimes, D.J. (ed), Nonculturable Microorganisms in the Environment. ASM Press, Washington D.C. https://doi.org/10.1007/978-1-4757-0271-2_16

Oliver, J.D., Nilsson, L. and Kjelleberg, S., 1991. Formation of nonculturable Vibrio vulnificus cells and its relationship to the starvation state. Applied and Environmental Microbiology, 57, 2640-2644.

Oregon Department of Human Services, 2003. Investigative Guidelines for Vibrio Parahaemolytics. http://vrdweb.hr.state.or.us

Ottaviani, D., Bacchiocchi, I., Masini, L., Leoni, F., Carraturo, A., Giammarioli, M. and Sbaraglia, G., 2001. Antimicrobial susceptibility of potentially pathogenic halophilic vibrios isolated from seafood. International Journal of Antibiotic Agents, 178, 135-140. https://doi.org/10.1016/S0924-8579(01)00358-2

Pan, L., Leung, P.C. and Gu, J.D.,2010. A new ColE1-like plasmid group revealed by comparative analysis of the replication proficient fragments of Vibrionaceae plasmids. Journal of
Microbiology and Biotechnology, 20, 1163-1178. https://doi.org/10.4014/jmb.1003.03007

Patel, M. and Isaacson, M., 1994. The effect of iron on the survival of Vibrio cholerae $\mathrm{O} 1$ in dechlorinated tap water. Transactions of the Royal Society of Tropical Medicine and Hygiene, $88,296-297$ https://doi.org/10.1016/0035-9203(94)90084-1

Petroni, A., Corso, A., Melano, R., Cacace, M.L., Bru, A.M., Rossi, A. and Galas, M., 2002. Plasmidic ExtendedSpectrum $\beta$-Lactamases in Vibrio cholerae O1 El Tor Isolates in Argentina. Antimicrobial Agents and Chemotherapy,46, 1462-1468. https://doi.org/10.1128/AAC.46.5.1462-1468.2002

QIAGEN, 2003. QIAprep spin miniprep kit protocol. p.22-23. In QIAprep Miniprep Handbook. Valencia, CA

Radu, S., Elhadi, N., Hassan, Z., Rusul, G., Lihan, S., Fifadara, N., Yuherman and Purwati, E., 1998. Characterization of Vibrio vulnificus isolated from cockles (Anadara granosa): antimicrobial resistance, plasmid profiles and random amplification of polymorphic DNA analysis. FEMS Microbiology Letters, $165,139-143$. https://doi.org/10.1111/j.1574-6968.1998.tb13138.x

Radu, S., Vincent, M., Apun, K., Rahim, R.A., Benjamin, P.G., Yuherman and Rusul, G., 2002. Molecular characterization of Vibrio cholerae O1 outbreak strains in Miri, Sarawak (Malaysia). Acta Tropica, 83, 168-176. https://doi.org/10.1016/S0001-706X(02)00110-9

Redenbach, M., Bibb, M., Gust, B., Seitz, B. and Spychaj, A., 1999. The linear plasmid SCP1 of Streptomyces coelicolor A3(2) possesses a centrally located Replication origin and shows significant homology to the transposon Tn4811. Plasmid, 42, 174-185. https://doi.org/10.1006/plas.1999.1419

Rhee, J. E., Rhee, J.H., Ryu, P.Y. and Choi, S.H., 2002. Identification of the cadBA operon from Vibrio vulnificus and its influence on survival to acid stress. FEMS Microbology Letters, 208, 245-251. https://doi.org/10.1111/j.1574-6968.2002.tb11089.x

Richards, F.J, 1959. A flexible growth function for empirical use. Journal of Experimental Botany, 10, 290-300. https://doi.org/10.1093/jxb/10.2.290

Roszak, D.B. and Colwell, R.R., 1987. Survival strategies of bacteria in the natural environment. Microbiological Reviews, 51, 365-379.

Rowe-Magnus, D.A. and Mazel, D., 2001. Integrons: natural tools for bacterial genome evolution. Current Opinion in Microbiology, 4, 565-569. https://doi.org/10.1016/S1369-5274(00)00252-6

Rowe-Magnus, D.A., Guérout, A.M. and Mazel, D., 1999. Superintegrons. Research in Microbiology, 150, 641-651. https://doi.org/10.1016/S0923-2508(99)00127-8

Rowe-Magnus, D.A., Guerout, A.M. and Mazel, D., 2002. Bacterial resistance evolution by recruitment of super-integron gene cassettes. Molecular Microbiology, 43, 1657-1669. https://doi.org/10.1046/j.1365-2958.2002.02861.x

Rubin, E.J., Lin, W., Mekalanos, J.J., and Waldor, M.K., 1998. Replication and integration of a Vibrio cholerae cryptic plasmid linked to the CTX prophage. Molecular Microbiology, $28,1247-1254$. https://doi.org/10.1046/j.1365-2958.1998.00889.x 
Said, B. and Drasar, B., 1996. Vibrio cholerae. p.1-17. In Drasar, B. S. and Forrest, B.D. (ed.), Cholera and the Ecology of Vibrio choleae. Chapman \& Hall, London. https://doi.org/10.1007/978-94-009-1515-2_1

Sakazaki, R, 1989. Bacteriology of Vibrio and related organisms. p.37-55. In Barua, D. and Greenberg III, W.B. (ed.), Cholera. Plenum Medical Book Company, New York and London.

Salyers, A. A. and Whitt, D.D., 2002. Vibrio cholerae, the Cause of cholera. p.363-380. In Bacterial Pathogenesis: A Molecular Approach. (2nd ed) ASM Press, Washington D. C.

Sambrook, J., Fritsch, E.F. and Maniatis, T., 1989a. Small scale preparations of plasmid DNA. p.1.25-1.31. In Molecular Cloning: A Laboratory Manual. (2nd ed). Cold Spring Harbor Laboratory Press, New York.

Sambrook, J., Fritsch, E.F. and Maniatis, T., 1989b. Preparation and examination of agrose gels. p.6.9- 6.15. In Molecular Cloning: A Laboratory Manual. (2nd ed). Cold Spring Harbor Laboratory Press, New York.

Sambrook, J., Fritsch, E.F. and Maniatis, T., 1989c. Preparation of fresh or frozen competent E. coli. p.1.76. In Molecular Cloning: A Laboratory Manual. (2nd ed). Cold Spring Harbor Laboratory Press, New York.

Sambrook, J., Fritsch, E.F. and Maniatis, T., 1989d. Transformation of E. coli by high-voltage electroporation (electrotranformation). p.1.75. In Molecular Cloning: A Laboratory Manual. (2nd ed). Cold Spring Harbor Laboratory Press, New York.

Sambrook, J., Fritsch, E.F. and Maniatis, T., 1989e. Rapid disruption of bacterial colonies to test the size of plasmids. p.1.32. In Molecular Cloning: A Laboratory Manual. (2nd ed). Cold Spring Harbor Laboratory Press, New York.

Sambrook, J., Fritsch, E.F. and Maniatis, T., 1989f. Identification of bacterial colonies that contain recombinant plasmids. p.1.85-1.110. In Molecular Cloning: A Laboratory Manual. (2nd ed). Cold Spring Harbor Laboratory Press, New York.

Sandaa, R. and Enger, O., 1994. Transfer in marine sediments of the naturally occurring plasmid pRAS1 encoding multiple antibiotic resistance. Applied and Environmental Microbiology, 60, 4234-4238.

Schepers, A., Thibault, W.J. and Lacroix, C., 2000. Comparison of simple neural networks and nonlinear regression models for descriptive modeling of Lactobacillus helveticus growth in pH-controlled batch cultures. Enzyme and Microbial Technology, 26, 431- 445. https://doi.org/10.1016/S0141-0229(99)00183-0

Sengupta, T.K., Chaudhuri, K., Majumdar, S., Lohia, A., Chatterjee, A.N. and Das,J., 1992. Interaction of Vibrio cholerae cells with beta-lactam antibiotics: emergence of resistant cells at a high frequency. Antimicrobial Agents and Chemotherapy, 36, 788-795. https://doi.org/10.1128/AAC.36.4.788

Shen, P, Zhou, H., Lai, H.Y. and Gu, J.D., 2006. Benthic infaunal composition and distribution at an intertidal wetland mudflat. Water, Air and Soil Pollution: Focus, 6, 575-581. https://doi.org/10.1007/s11267-006-9042-5

Shen, P.P., Zhou, H., Zhao, Z., Yu, X.Z. and Gu, J.D., 2012. Evaluation of sampling sizes onthe intertidal macroinfauna assessment in a subtropical mudflat of Hong Kong. Ecotoxicology, 21, 1706-1716.

https://doi.org/10.1007/s10646-012-0968-2
Shukla, B.N., Singh, D.V. and Sanyal, S.C., 1995. Attachment of non-culturable toxigenic Vibrio cholera $\mathrm{O} 1$ and non-O1 and Aeromonas spp.to the aquatic arthropod Gerris spinolae and plants in the River Ganga, Varanasi. FEMS Immunology and Medical Microbiology, 12, 113-120.

https://doi.org/10.1111/j.1574-695X.1995.tb00182.x

Simidu, U. and Tsukamoto, K., 1985. Habitat segregation and biochemical activities of marine members of the family Vibrionaceae. Applied Microbiology, 50, 781-790.

Simpson, L.M.and Oliver, J.D., 1983. Siderophore production by Vibrio vulnificus. Infection and Immunity, 41, 644-649.

Sizemore, R.K. and Colwell, R.R., 1977. Plasmids carried by antibiotic-resistant marine bacteria. Antimicrobial Agents and Chemotherapy, 12, 373-382.

https://doi.org/10.1128/AAC.12.3.373

Smalla, K. and Sobecky, P.A., 2002. The prevalence and diversity of mobile genetic elements in bacterial communities of different environmental habitats: insights gained from different methodological approaches. FEMS Microbiology Ecology, $42,165-175$. https://doi.org/10.1111/j.1574-6941.2002.tb01006.x

Sobecky, P.A, 1999. Plasmid ecology of marine sediment microbial communities. Hydrobiologia, 401, 9-18. https://doi.org/https://doi.org/10.1023/A:1003726024628

Sobecky, P.A., Mincer, T.J., Chang, M.C. and Helinski, D.R., 1997. Plasmids isolated from marine sediment microbial communities contain replication and incompatibility regions unrelated to those of known plasmid groups. Applied and Environmental Microbiology, 63, 888-895.

Sobecky, P.A., Mincer, T.J., Chang, M.C, Toukdarian, A. and Helinski, D.R., 1998. Isolation of broad-host-range replicons from marine sediment bacteria. Applied and Environmental Microbiology, 64, 2822-2830.

Solar, D.G., Giraldo, R., Ruiz-Echevarría, M.J., Espinosa, M. and Díaz-Orejas, R., 1998. Replication and control of circular bacterial plasmids. Microbiology and Molecular Biology Reviews, 62, 434-464.

Stelma, G.N., Reyes Jr, A.L., Peeler, J.T., Johnson, C.H. and Spaulding, P.L., 1992. Virulence characteristics of clinical and environmental isolates of Vibrio vulnificus. Applied and Environmental Microbiology, 58, 2776-2782.

Storz, G. and Imlay, J.A., 1999. Oxidative stress. Current Opinion in Microbiology, 2, 188-194. https://doi.org/10.1016/S1369-5274(99)80033-2

Stratagene, 2002. Bluescript II Phagemid Vectors: Instruction Manual. La Jolla, CA, USA.

Strom, M.S. and Paranjpye, R.N., 2000. Epidemiology and pathogenesis of Vibrio vulnificus. Microbes and Infections, 2, $177-$ 188. https://doi.org/10.1016/S1286-4579(00)00270-7

Tabtieng, R., Wattanasri, S., Echeverria, P., Seriwatana, J., Bodhidatta, L., Chatkaeomorakot, A. and Rowe, B., 1989. An epidemic of Vibrio cholerae El Tor Inaba resistant to several antibiotics with a conjugative group $\mathrm{C}$ plasmid coding for type II dihydrofolate reductase in Thailand. American Journal of Tropical Medicine and Hygiene, 41, 680-686. https://doi.org/10.4269/ajtmh.1989.41.680

Tam, N.F.Y. and Wong, Y.S., 2000. Introduction. p.1-32. In Hong Kong Mangroves. City University of Hong Kong Press, Hong Kong. 
Tamplin, M., 1994. The ecology of Vibrio vulnificus. p.75-85. In Watkins. W. and McCarthy, S. (ed.), Proceedings of the 1994 Vibrio vulnificus Workshop. Office of Seafood. Washington, D.C.

Tamplin, M.L., 1991. Environmental spread of Vibrio cholerae in Peru. Lancet, 338, 1216-1217. https://doi.org/10.1016/0140-6736(91)92089-K

Tamplin, M.L., 2001. Coastal vibrios: identifying relationships between environmental condition and human disease. Human and Ecological Risk Assessment, 7, 1437-1445. https://doi.org/10.1080/20018091095113

Tamplin, M.L., Gauzens, A.L., Huq, A., Sackand, D.A., Colwell, R.R., 1990. Attachment of Vibrio cholerae serogroup O1 to zooplankton and phytoplankton of Bangladesh Waters. Applied and Environmental Microbiology, 56, 1977-1980.

Tanaka, N., Kawano, G. and Kinoshita, T., 1971. Chromosomal location of a fusidic acid resistant marker in Escherichia coli. Biochemistry and Biophysics Research Communication, 42, 564-567. https://doi.org/10.1016/0006-291X(71)90408-6

The MathWorks Inc, 2000. Optimization Toolbox User's Guide (Version 2.1), The MathWorks, Inc. Natick, Massachusetts.

Thompson, J.R., Pacocha, S., Pharino, C., Klepac-Ceraj, V., Hunt, D.E., Benoit, J., Sharma-Rupavtam, R., Distel, D.L., Polt, M.F., 2005. Genotypic diversity within a natural coastal bacterioplankton population. Science, 307, 1311-1313. https://doi.org/10.1126/science.1106028

Threlfall, E.J., Rowe, B. and Huq, I., 1980. Plasmid-encoded multiple antibiotic resistance in Vibrio cholerae El Tor from Bangladesh. Lancet, 1, 1247-1248.

https://doi.org/10.1016/S0140-6736(80)91701-8

Tison, D.L, 1999. Vibrio. p.497-506. In Murray, P.R., Baron, E.J., Pfaller, M.A., Tenover, F.C. and Yolken, R.H. (ed.), Manual of Clinical Microbiology (7th ed). ASM Press, Washington D.C.

Tolmasky, M.E., Actis, L.A. and Crosa, J.H., 1993. Virulence plasmids. p.99. In Hardy, K. G. (ed.), Plasmids: A practical approach. (2nd ed). IRL Press at Oxford University Press Inc, New York.

Tomoeda, M., Inuzuka, M., Kubo, N. and Nakamura, S., 1968. Effective elimination of drug resistance and sex factors in Escherichia coli by sodium dodecyl sulfate. Journal of Bacteriology, 95, 1078-1089.

Touati, D, 2000. Iron and oxidative stress in bacteria. Archives of biochemistry and biophysics, 373, 1-6. https://doi.org/10.1006/abbi.1999.1518

Touati, D., Jacques, M., Tardat, B., Bouchard, L. and Despied, S., 1995. Lethal oxidative damage and mutagenesis are generated by iron in $\Delta$ fur mutants of Escherichia coli: protective role of superoxide dismutase. Journal of Bacteriology, 177, 2305-2314.

https://doi.org/10.1128/jb.177.9.2305-2314.1995

Trevors, J.T, 1986. Plasmid curing in bacteria. FEMS Microbiology Reviews, 32, 149-157. https://doi.org/10.1111/j.1574-6968.1986.tb01189.x

Tsim, S. T. and Lock, F. N. Y., 2002. Knowing Ramsar Wetland. Cosmos Book Ltd. Hong Kong.

van Vilet, H.M.A., Ketley, J.M., Park, S.F. and Penn, C.W., 2002. The role of iron in Campylobacter gene regulation, metabolism and oxidative stress defense. FEMS Microbiology Review, 26, 173-186.

https://doi.org/10.1111/j.1574-6976.2002.tb00609.x

von der Haar, B. and Schrempf, H., 1995. Purification and characterization of a novel extracellular Streptomyces lividans 66 enzyme inactivating fusidic acid. Journal of Bacteriology, 177, 152-155. https://doi.org/10.1128/jb.177.1.152-155.1995

Waldor, M.K., Tschape, H. and Mekalanos, J.J., 1996. A new type of conjugative transposon encodes resistance to sulfamethoxazole, trimethoprim, and streptomycin in Vibrio cholerae O139. Journal of Bacteriology, 178, 4157-4165. https://doi.org/10.1128/jb.178.14.4157-4165.1996

Walsh, C, 2003a. Antibiotics: initial concepts. p.5-9. In Antibiotics: Actions, Origins, Resistance. ASM Press, Washington D.C. https://doi.org/10.1128/9781555817886.ch1

Walsh, C, 2003b. Natural and producer immunity versus acquired resistance. p.91-106. In Antibiotics: Actions, Origins, Resistance. ASM Press, Washington D.C. https://doi.org/10.1128/9781555817886.ch7

Walsh, C, 2003c. Antibiotic resistance by replacement or modification of the antibiotic target. p.143-154. In Antibiotics: Actions, Origins, Resistance. ASM Press, Washington D.C. https://doi.org/10.1128/9781555817886.ch10

Walsh, C, 2003d. Enzymatic destruction or modification of the antibiotic by resistant bacteria. p.107-123. In Antibiotics: Actions, Origins, Resistance. ASM Press, Washington D.C. https://doi.org/10.1128/9781555817886.ch8

Walsh, C, 2003e. Antibiotic resistance by efflux pumps. p.125-142. In Antibiotics: Actions, Origins, Resistance. ASM Press, Washington D.C. https://doi.org/10.1128/9781555817886.ch9

Wang, Y., and Gu, J.D., 2005. Influence of temperature, salinity and $\mathrm{pH}$ on the growth of environmental isolates of Aeromonas and Vibrio species isolated from Mai Po and the Inner Deep Bay Nature Reserve Ramsar site of Hong Kong. Journal of Basic Microbiology, 45, 83-93. https://doi.org/10.1002/jobm.200410446

Wang, Y., Leung, P.C., Qian, P. and Gu, J.D., 2004. Effects of UV, $\mathrm{H}_{2} \mathrm{O}_{2}$ and $\mathrm{Fe}^{3+}$ on the growth of four environmental isolates of Aeromonas and Vibrio species isolated from a mangrove environment. Microbes and Environments, 19, 163-171. https://doi.org/10.1264/jsme2.19.163

Wang, Y., Leung, P.C., Qian, P. and Gu, J.D., 2006. Antibiotic resistance and plasmid profile of environmental isolates of Vibrio species from Mai Po Nature Reserve, Hong Kong. Ecotoxicology, 15, 371-378. https://doi.org/10.1007/s10646-006-0078-0

Warner, J.M. and Oliver, J.D., 1999. Randomly amplified polymorphic DNA analysis of clinical and environmental isolates of Vibrio vulnificus and other Vibrio species. Applied and Environmental Microbiology, 65, 1141-1144.

Wu, H.Z., Zhang, H.Z., Lu, C.X., Liang, N., Jin, H.Y., Ma.Y. and Zhang, Y.X., 2003. DNA sequencing of a plasmid with virulence from marine fish pathogen Vibrio anguillarum. Acta Biochimica \&Biophysica Sinica, 35, 956-959.

Wu, R.S.S, 1999. Eutrophication, water borne pathogens and xenobiotic compounds: environmental risks and challenges. Marine Pollution Bulletin, 39, 11-22. https://doi.org/10.1016/S0025-326X(99)00014-4 
Yamamoto, T., Nair, G.B., Albert, M.J., Parodi, C.C. and Takeda, Y., 1995. Survey of in vitro susceptibilities of Vibrio cholerae O1 and O139 to antimicrobial agents. Antimicrobial Agents and Chemotherapy, 39, 241-244. https://doi.org/10.1128/AAC.39.1.241

Yoo, M.H., Huh, M.D., Kim, E.H., Lee, H.H. and H.D. Jeong, 2003. Characterization of chloramphenicol acetyltransferase gene by multiplex polymerase chain reaction in multidrugresistant strains isolated from aquatic environments. Aquaculture, 217, 11-21. https://doi.org/10.1016/S0044-8486(02)00169-2

Zanetti, S., Spanu, T., Deriu, A., Romano, L., Sechiand, L.A., Fadda, G., 2001. In vitro susceptibility of Vibrio spp. isolated from the environment. International Journal of Antibiotic Agents, 17, 407-409. https://doi.org/10.1016/S0924-8579(01)00307-7

Zgurskaya, H.I, 2002. Molecular analysis of efflux pump-based antibiotic resistance. International Journal of Medical Microbiology, 292, 95-106. https://doi.org/10.1078/1438-4221-00195

Zhang, R.F. and Gu, J.D., 2009. Complete sequence of plasmid pMP1 from the marine environmental Vibrio vulnificus and location of its replication origin. Marine Biotechnology, 11, 456-462. https://doi.org/10.1007/s10126-008-9160-3

Zhang, R., Wang, Y. and Gu, J.D., 2006. Identification of environmental plasmid-bearing Vibrio species isolated from polluted and pristine marine reserves of Hong Kong and resistance to antibiotics and mercury. Antoine van Leeuvenhoek - International Journal of General and Molecular Microbiology, 89, 307-315.

https://doi.org/10.1007/s10482-005-9032-z
Zhang, R., Wang, Y., Leung, P.C. and Gu, J.D., 2007. pVC, a small cryptic plasmid from the environmental isolate of Vibrio cholerae MP-1. The Journal of Microbiology, 45, 193-198.

Zhang, R., Pan, L., Zhao, Z. and Gu, J.D., 2012. High incidence of plasmids in marine Vibrio species isolated from Mai Po Nature Reserve of Hong Kong. Ecotoxicology, 21, 16611668. https://doi.org/10.1007/s10646-012-0939-7

Zhang, Z.G. and Gurr, S.J., 2002. A "step down" PCR-based technique for walking into and the subsequent direct sequence analysis of flanking genomic DNA. p.343-352. In Chen, B.Y and Janes, H.W. (ed.). PCR Cloning Protocols. Humana Press, New Jersey. https://doi.org/10.1385/1-59259-177-9:343

Zhao, Z., Zhuang, Y.X. and Gu, J.D., 2012. Abundance, composition and vertical distribution of polycyclic aromatic hydrocarbons in sediments of the Mai Po Inner Deep Bay of Hong Kong. Ecotoxicology, 21, 1734-1742. https://doi.org/10.1007/s10646-012-0951-y

Zhao, Z.Y., Chu, Y.L. and Gu,J.D., 2012. Distribution and sources of polycyclic aromatic hydrocarbons in sediments of the Mai Po Inner Deep Bay Ramsar Site in Hong Kong. Ecotoxicology, 21, 1743-1752. https://doi.org/10.1007/s10646-012-0948-6

Zheng, G.J., Lam, M.H.W., Lam, P.K.S., Richardson, B.J., Man, B.K.W. and Li, A.M.Y., 2000. Concentrations of persistent organic pollutants in surface sediments of the mudflat and mangroves at Mai Po Marshes Nature Reserve, Hong Kong. Marine Pollution Bulletin, 40, 1210-1214. https://doi.org/10.1016/S0025-326X(00)00190-9

Zuppardo, A.B. and Siebeling, R.J., 1998. An epimerase gene essential for capsule synthesis in Vibrio vulnificus. Infection and Immunity, 66, 2601-2606. 